Geological Society, London, Special Publications

\title{
Landscape evolution in Martian mid-latitude regions: insights from analogous periglacial landforms in Svalbard
}

E. Hauber, D. Reiss, M. Ulrich, et al.

Geological Society, London, Special Publications 2011; v. 356; p. 111-131 doi: 10.1144/SP356.7

$\begin{array}{ll}\begin{array}{l}\text { Email alerting } \\ \text { service }\end{array} & \begin{array}{l}\text { click here to receive free e-mail alerts when new } \\ \text { articles cite this article }\end{array} \\ \begin{array}{l}\text { Permission } \\ \text { request }\end{array} & \begin{array}{l}\text { click here to seek permission to re-use all or part of } \\ \text { this article }\end{array} \\ \text { Subscribe } & \begin{array}{l}\text { click here to subscribe to Geological Society, } \\ \text { London, Special Publications or the Lyell Collection }\end{array}\end{array}$

Notes

Downloaded by guest on August 22, 2011

(C) The Geological Society of London 2011 


\title{
Landscape evolution in Martian mid-latitude regions: insights from analogous periglacial landforms in Svalbard
}

\author{
E. HAUBER ${ }^{1 *}$, D. REISS ${ }^{2}$, M. ULRICH ${ }^{3}$, F. PREUSKER ${ }^{1}$, F. TRAUTHAN ${ }^{1}$, M. ZANETTI ${ }^{2}$, \\ H. HIESINGER ${ }^{2}$, R. JAUMANN ${ }^{1}$, L. JOHANSSON ${ }^{4}$, A. JOHNSSON ${ }^{4}$, S. VAN GASSELT ${ }^{5} \&$ \\ M. OLVMO ${ }^{4}$ \\ ${ }^{1}$ Institut für Planetenforschung, DLR, Rutherfordstrasse 2, 12489 Berlin, Germany \\ ${ }^{2}$ Institut für Planetologie, Westfälische Wilhelms-Universität, 48149 Münster, Germany \\ ${ }^{3}$ Alfred-Wegener-Institut, 14473 Potsdam, Germany \\ ${ }^{4}$ Department of Earth Sciences, University of Gothenburg, Box 460, \\ SE-405 30 Göteborg, Sweden \\ ${ }^{5}$ Institut für Geologische Wissenschaften, Freie Universität Berlin, \\ Malteserstrasse 74-100, 12249 Berlin, Germany \\ *Corresponding author (e-mail: Ernst.Hauber@dlr.de)
}

\begin{abstract}
Periglacial landforms on Spitsbergen (Svalbard, Norway) are morphologically similar to landforms on Mars that are probably related to the past and/or present existence of ice at or near the surface. Many of these landforms, such as gullies, debris-flow fans, polygonal terrain, fractured mounds and rock-glacier-like features, are observed in close spatial proximity in mid-latitude craters on Mars. On Svalbard, analogous landforms occur in strikingly similar proximity, which makes them useful study cases to infer the spatial and chronological evolution of Martian coldclimate surface processes. The analysis of the morphological inventory of analogous landforms on Svalbard and Mars allows the processes operating on Mars to be constrained. Different qualitative scenarios of landscape evolution on Mars help to better understand the action of periglacial processes on Mars in the recent past.
\end{abstract}

Many young landforms on Mars that were probably formed by exogenic processes show a latitudedependent geographical distribution. They include surface mantling (Kreslavsky \& Head 2000; Mustard et al. 2001; Morgenstern et al. 2007), lobate debris aprons, lineated valley fill and concentric crater fill (e.g. Squyres 1978), viscous flow features (Milliken et al. 2003), gullies (Balme et al. 2006; Kneissl et al. 2010) and patterned ground (Mangold 2005). Other landforms, such as pedestal craters, seem to indicate a preservation of near-surface ice and are also latitude-dependent (Kadish et al. 2009). Collectively, these landforms are hypothesized to represent the surface records of Martian ice ages (e.g. Head et al. 2003) that were induced by astronomical forcing (Laskar et al. 2004) and associated climate changes (Toon et al. 1980; Jakosky \& Carr 1985; Mischna et al. 2003; Forget et al. 2006; Schorghofer 2007). Previous authors often considered only one of such feature classes in isolation (e.g. gullies), without taking into account the geomorphological context. It was not until the recent advent of high-resolution data from orbit and the in situ investigation of
Martian high-latitude terrain by the Phoenix Lander that a more integrated view of diverse landforms into a landscape evolution model were allowed to develop (e.g. Balme \& Gallagher 2009; Levy et al. 2009a). A more comprehensive investigation of the full assemblage of landforms by means of landscape analysis, however, has the potential to reduce the ambiguity in interpreting landforms and to reveal the evolution of the climatic environment in more detail. The phenomenon of equifinality (i.e. similar-looking landforms resulting from diverse processes) is particularly problematic in planetary geomorphology, where the morphology as inferred from remote-sensing data such as images and digital elevation models (DEM) is the only observable component. An instructive example is the case of pitted mounds on Mars, which have been interpreted in the past as modified impact craters, rootless cones, cinder cones and pingos. In some of the studies that favoured pingos, the interpretations were based on poor evidence and attracted criticism from terrestrial permafrost researchers (Humlum \& Christiansen 2008). Here we present permafrost landforms from Svalbard 
(Norway) as useful terrestrial analogues for the suite of possible periglacial landforms that are typically found at mid-latitudes on Mars. We build on our previous investigations of gullies and fans (Hauber et al. 2009), and include a number of classical periglacial landforms (patterned ground, rock glaciers, pingos) that all have close morphological analogues on Mars. Based on this comparison, we propose several evolutionary scenarios that could help to develop a better understanding of the sequential formation of the Martian landforms.

\section{Permafrost and periglacial features on Mars and Svalbard}

Mars may be regarded as a permafrost planet, following the definition of permafrost given by van Everdingen (2005): 'Ground (soil or rock [...]) that remains at or below $0{ }^{\circ} \mathrm{C}$ for at least two consecutive years, regardless of the water content'. In fact, the shallow subsurface of Mars probably experienced temperatures that were continuously below $0{ }^{\circ} \mathrm{C}$ for most of its history (e.g. Shuster \& Weiss 2005). In the current Martian climate, ground ice is thought to be stable only at higher latitudes (e.g. Leighton \& Murray 1966; Smoluchowski 1968; Fanale et al. 1986; Mellon \& Jakosky 1993) and, indeed, the Phoenix mission has provided unambiguous evidence for very shallow and rather pure ground ice at a latitude of $68.2^{\circ} \mathrm{N}$ (Smith et al. 2009). The latitudinal range of ice stability is, however, a function of the planet's obliquity (i.e. the tilt of the rotational axis). Mars' obliquity is assumed to vary widely (Ward 1973; Touma \& Wisdom 1993), and at an obliquity exceeding $32^{\circ}$ (today $c .25^{\circ}$ ) ground ice becomes globally stable (Mellon \& Jakosky 1995). An obliquity exceeding about $27^{\circ}$ is required for ice to be stable at latitudes of $30^{\circ}$ and higher (Mellon \& Jakosky 1995, their fig. 10d). Other factors that affect the stability of ground ice are geographical variability, soil properties, rocks and local slopes (see Mellon et al. 2009 and references therein). The large and frequent oscillations of Mars' obliquity (an obliquity cycle spans 117000 years: Laskar et al. 2004) should have a significant influence on the volatile distribution on the surface (Jakosky et al. 1995), and climate modelling using global circulation models (GCM) confirms this view (Levrard et al. 2004; Forget et al. 2006; Madeleine et al. 2009). It appears likely that water ice was frequently driven from the poles towards lower latitudes during periods of higher obliquities, when the polar regions received more incoming solar energy (Forget et al. 2006). In contrast, water ice was redistributed towards higher latitudes during the following periods of lower obliquities (Levrard et al. 2004). Ground ice can thus be expected to be a significant factor in Martian landscape evolution. Recent observations, indeed, showed that near-surface water ice is present even in mid- and low-latitude regions (Holt et al. 2008; Byrne et al. 2009; Vincendon et al. $2010 a, b$ ), in contrast to expectations from theoretical modelling (see above).

To complement theoretical modelling, comparisons with terrestrial analogues are mandatory to constrain the action of periglacial processes and the corresponding landscape evolution on Mars. Present-day Mars is cold and dry, so surface processes acting in terrestrial cold deserts should be considered as useful analogues. The closest coldclimate analogue to Mars on Earth are the Antarctic Dry Valleys (Anderson et al. 1972; Marchant \& Head 2007, 2010), a polar desert environment with exceptionally cold and dry conditions (Doran et al. 2002) and correspondingly small active layer depth (Bockheim et al. 2007). Other polar regions also display morphological analogues to Mars, however, and the archipelago of Svalbard and its largest island, Spitsbergen (Fig. 1a), offer a diverse inventory of periglacial landforms in close spatial proximity. Terrain phenomena such as pingos, ice-wedge polygons and rock glaciers are widespread, especially in the dry central regions of Spitsbergen. Periglacial features such as solifluction lobes occur primarily in the more humid western regions. Various forms of patterned ground, such as stone circles and stripes, are widespread and well developed (see Åkerman 1987 for a review of periglacial landforms of Svalbard). Examples of periglacial morphologies are closely located to the settlements of Longyearbyen and Ny Alesund on the main island of Spitsbergen, making them very useful morphological analogues to Martian cold-climate landforms. Major controls on permafrost aggradation are wind, snow and avalanches (Humlum 2005). A particularly interesting aspect of permafrost on Svalbard is its interaction with glaciers (Etzelmüller \& Hagen 2005) because such interaction is often neglected in the literature (Haeberli 2005) but may be highly important on Mars.

\section{Data}

Martian surface features were analysed using highresolution images of the CTX (Context Camera) and HiRISE (High Resolution Imaging Science Experiment) cameras, which have spatial resolutions of 5-6 m per pixel and approximately $30 \mathrm{~cm}$ per pixel, respectively. An airborne version of the HRSC (High Resolution Stereo Camera) was used for the acquisition of stereo and colour 
(a)

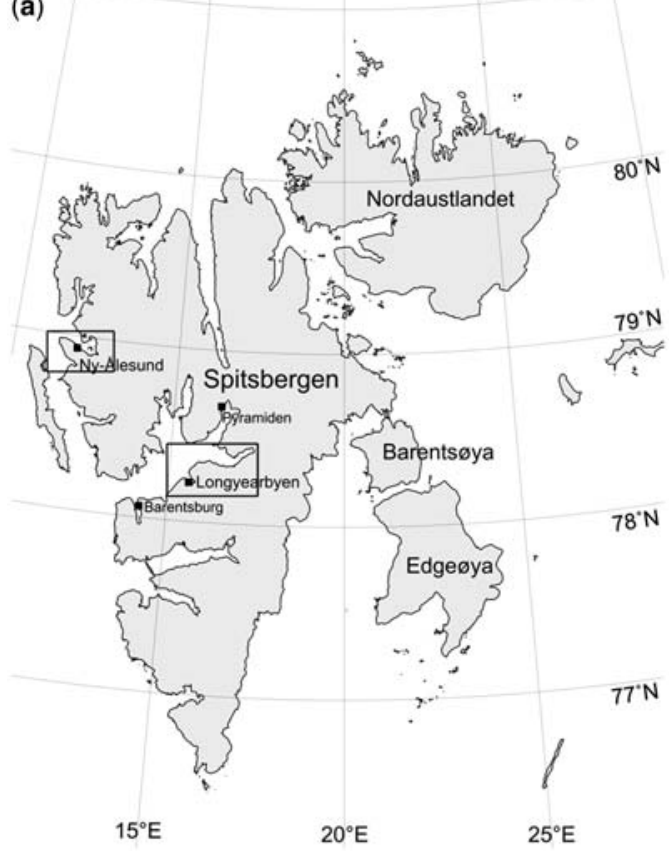

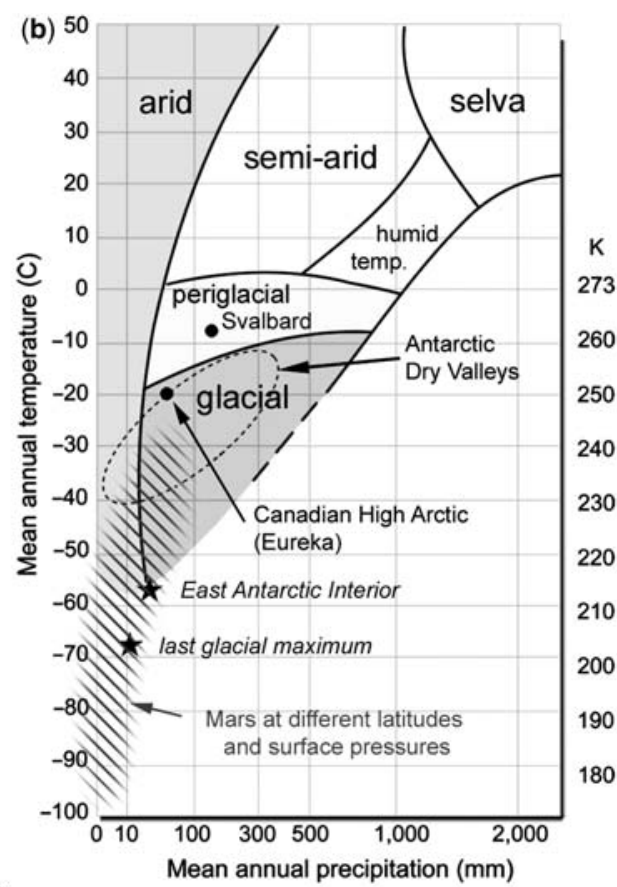

(d)

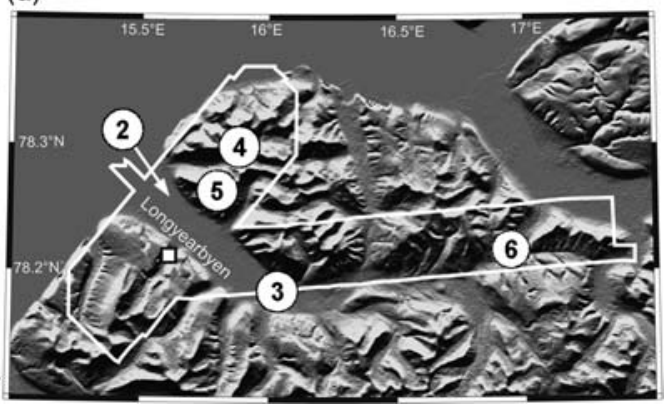

(c)

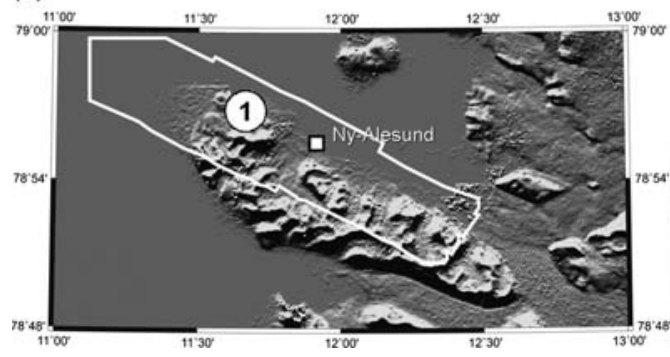

Fig. 1. Location and climate of study areas on Svalbard. (a) Map of Svalbard with study areas (boxes, see c and d).
(b) Climate zones and morphogenetic regions on Earth; modified from Baker (2001) and Head \& Marchant (2007). The climatic conditions on Mars (present and inferred past) are indicated by the hatched area. (c) Study area on the Brøgger Peninsula (shaded elevation model derived from ASTER data). (d) Study area in Adventdalen (shaded elevation model derived from Advanced Spaceborne Thermal Emission and Reflection Radiometer (ASTER) data). Numbers in (c) and (d) mark the geographical locations mentioned in the text: 1, Stuphallet; 2, Adventfjord; 3, Adventdalen; 4, Hannaskogdalen; 5, Hiorthfjellet; 6, Eskerdalen. Image credit: Univ. Münster/NASA/GSFC/METI/ ERSDAC/JAROS/US-Japan ASTER Science Team; see prelim viii for acronym definitions.

images of Spitsbergen. HRSC-AX is a multi-sensor push broom instrument with nine CCD (chargecoupled device) line sensors mounted in parallel. It simultaneously obtains high-resolution stereo, multi-colour and multi-phase images. The particular value of HRSC-AX is the stereo capability, which allows it to systematically produce high-resolution digital elevation models (DEM) with grid sizes of between $50 \mathrm{~cm}$ and $1 \mathrm{~m}$ (Wewel et al. 2000; Scholten \& Gwinner 2004; Gwinner et al. 2005, 2006, 2009, 2010; Scholten et al. 2005). The HRSC-AX flight campaign in July-August 2008 covered a total of seven regions in Svalbard: (i) Longyearbyen and the surrounding area of Adventfjorden (all place names on Svalbard are as given as in the topographic map series, scale 1:100 000, published by the Norsk Polarinstitutt, Troms $\varnothing$, Sheets C9 and A7); (ii) large parts of Adventdalen; (iii) large parts of the Brøggerhalvøya (halvøya means peninsula) in western Spitsbergen; (iv) the Bockfjorden area in northern Spitsbergen; (v) the NE shore of the Palanderbukta and the margin of the adjacent ice cap in 
Nordaustlandet; (vi) an area on Prins Karls Forland; and (vii) the area of the abandoned Russian mining settlement of Pyramiden together with the nearby Ebbedalen. The landforms discussed in this study are located on the Brøgger Peninsula and in Adventdalen and its vicinity (Fig. 1a). In two field campaigns in 2008 and 2009, both of the areas covered by HRSC-AX were visited.

\section{The Svalbard climate}

The present climate of Svalbard is arctic (Fig. 1b). The mean annual air temperature at the airport in Longyearbyen, which is located only a few kilometres from the study area of Adventdalen, ranges between about $-6{ }^{\circ} \mathrm{C}$ at sea level and -15 ${ }^{\circ} \mathrm{C}$ in the high mountains (Hanssen-Bauer \& Førland 1998). Annual precipitation is low and reaches only about $180 \mathrm{~mm}$ in central Spitsbergen (Table 1). The central part of Spitsbergen can, therefore, be considered to be a polar (semi)desert, which is defined as an area with an annual precipitation of less than $250 \mathrm{~mm}$ and a mean temperature during the warmest month of less than $10{ }^{\circ} \mathrm{C}$ (Walker 1997). About 60\% of Svalbard is covered by glaciers and ice caps, and relatively small glaciers and ice caps are situated on many massifs and valleys around Adventdalen. The unglaciated part of Svalbard is characterized by continuous permafrost, which has a thickness of $10-40 \mathrm{~m}$ in coastal regions, about $100 \mathrm{~m}$ in the major valleys and more than $450 \mathrm{~m}$ in the highlands (Liestøl 1976; Isaksen et al. 2000; Sollid et al. 2000).

\section{Morphological comparisons between Mars and Svalbard}

Many possible glacial and periglacial landforms are located in mid-latitude impact craters on Mars. This specific geological setting provides ideal study cases because there is high relief present at the crater walls, and the opportunity to study the effects of insolation variations because craters are axisymmetric features and their inner walls have an azimuthal range of the entire $360^{\circ}$. It has been found by many previous researchers that the polefacing walls of impact craters are particularly prone to be shaped by glacial and periglacial processes (e.g. Dickson et al. 2007). In this section the inventory of such landforms is briefly reviewed and compared to analogous landforms on Svalbard. We note here that all of these features have been found in craters on Mars, sometimes several of them in the same crater but, so far, no crater has been found that hosts all of them together.

\section{Martian landforms}

Many landforms on Mars that are morphologically similar to terrestrial glacial and periglacial landforms occur in the middle latitudes, between about $30^{\circ}$ and $60^{\circ}$ (Fig. 2). They are situated along the high-relief belt of the Martian dichotomy boundary and other regions of high relief (e.g. Pierce \& Crown 2003; Chuang \& Crown 2005; Head et al. 2006; van Gasselt et al. 2010), as well as in flat-lying regions such as Utopia Planitia (Soare et al. 2005; Morgenstern et al. 2007; Lefort et al. 2009). A

Table 1. Climate at Svalbard Airport. For the series of observed and modelled annual and seasonal temperature means and precipitation sums from 1912 to 1993 the following values are given: mean, standard deviation, absolute minimum and absolute maximum. SD, standard deviation; Corr., correlation coefficient between observed and modelled temperature and precipitation series (data from Hanssen-Bauer \& Forland 1998). For comparison, the mean annual air temperature at the floor of the Dry Valleys in Antarctica ranges from -14.8 to $-30^{\circ} \mathrm{C}$, and the mean annual precipitation is $\ll 100 \mathrm{~mm}$, but can be as low as $13 \mathrm{~mm}$ (Doran et al. 2002; Campbell \& Claridge 2004)

\begin{tabular}{|c|c|c|c|c|c|c|c|c|c|c|}
\hline Season & & Mean & SD & Min. & Max. & Mean & SD & Min. & Max. & Corr. \\
\hline & & \multicolumn{4}{|c|}{ Observed $T\left({ }^{\circ} \mathrm{C}\right)$} & \multicolumn{4}{|c|}{ Modelled $T\left({ }^{\circ} \mathrm{C}\right)$} & \\
\hline Year & & -6.3 & 1.7 & -12.2 & -3.1 & -6.4 & 1.0 & -8.9 & -4.0 & 0.61 \\
\hline Winter & (DJF) & -14.0 & 3.6 & -23.2 & -7.6 & -14.1 & 2.4 & -19.1 & -9.1 & 0.62 \\
\hline Spring & (MAM) & -10.8 & 2.4 & -19.3 & -6.7 & -10.8 & 1.7 & -15.2 & -7.5 & 0.58 \\
\hline Summer & $(\mathrm{JJA})$ & 4.3 & 0.7 & 2.5 & 6.1 & 4.2 & 0.5 & 3.2 & 5.4 & 0.54 \\
\hline \multirow[t]{2}{*}{ Autumn } & $(\mathrm{SON})$ & -4.8 & 2.0 & -11.3 & -1.3 & -4.9 & 1.5 & -8.7 & -1.8 & 0.66 \\
\hline & & \multicolumn{4}{|c|}{ Observed $P(\mathbf{m m})$} & \multicolumn{4}{|c|}{ Modelled $\boldsymbol{P}$ (mm) } & \\
\hline Year & & 180.7 & 49.8 & 86.4 & 317.0 & 178.7 & 33.5 & 93.5 & 286.6 & 0.54 \\
\hline Winter & (DJF) & 53.4 & 24.3 & 16.8 & 140.0 & 52.8 & 11.5 & 24.5 & 86.8 & 0.40 \\
\hline Spring & (MAM) & 35.6 & 10.4 & 6.4 & 125.9 & 34.3 & 13.6 & 10.6 & 65.5 & 0.60 \\
\hline Summer & (JJA) & 43.7 & 21.2 & 3.0 & 114.0 & 43.7 & 18.7 & 8.3 & 100.8 & 0.57 \\
\hline Autumn & $(\mathrm{SON})$ & 48.1 & 17.0 & 18.4 & 109.0 & 47.9 & 13.1 & 21.5 & 79.1 & 0.54 \\
\hline
\end{tabular}

DJF, December, January, February; MAM, March, April, May; JJA, June, July, August; SON, September, October, November. 


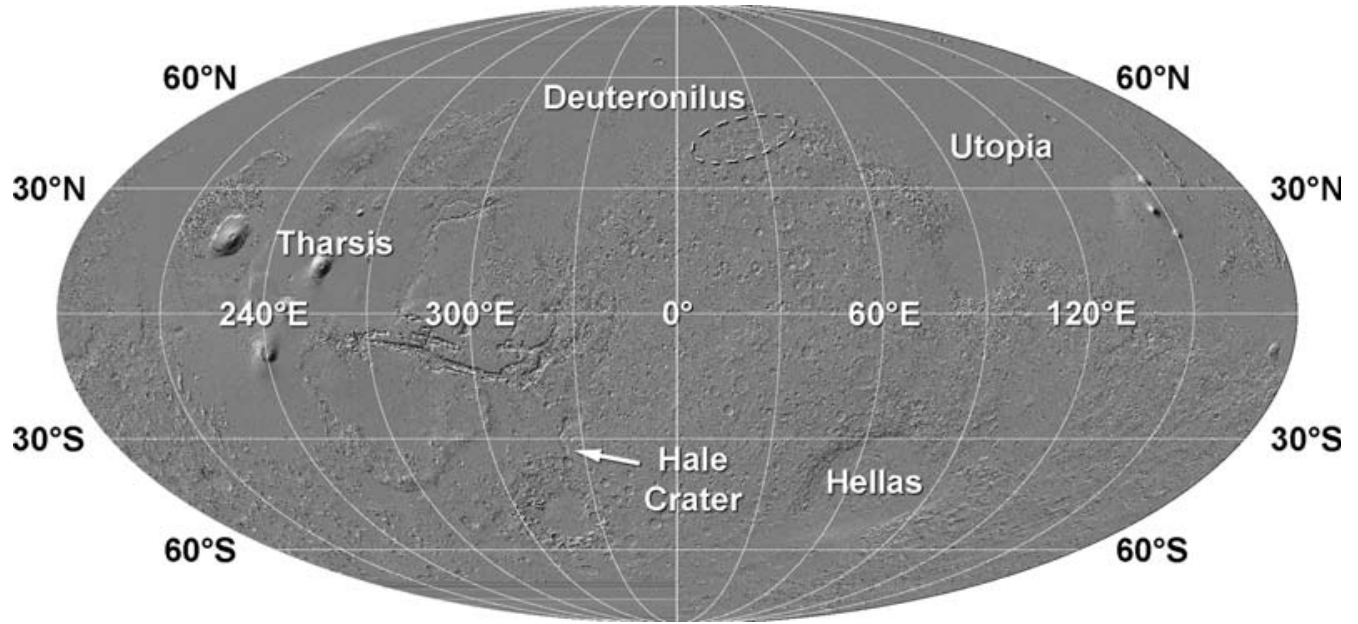

Fig. 2. Locations of regional features on Mars mentioned in the text (shaded version of the MOLA DEM). Image credit: DLR/NASA/JPL/MOLA Science Team.

particularly interesting setting is the pole-facing inner wall of impact craters. Most gullies (Fig. 3a) have been found on such walls, especially in the southern hemisphere (Dickson et al. 2007). On the base of some gullies, spatulate depressions are delineated towards the inner crater floor by arcuate ridges, which have been compared to moraines (e.g. Berman et al. 2005, fig. 1). Other landforms of possible periglacial origin have been observed in close spatial association with the crater-wall gullies, including polygons (Fig. 4a) (Levy et al. 2009c), patterned ground (Fig. 5a) (Mangold 2005), lobate features (Figs 6a \& 7a) (Milliken et al. 2003) and fractured mounds (Fig. 8a)
(Dundas et al. 2008). The unique occurrence of diverse possible periglacial landforms within a small area with considerable relief makes such craters an ideal study case for the action of periglacial processes on Mars. In the following, they will be compared with terrestrial analogues on Spitsbergen. Based on this comparison, possible scenarios of landscape evolution on Mars will be outlined.

\section{Svalbard landforms}

The main study site is Adventdalen, an approximately $40 \mathrm{~km}$-long and up to about $3 \mathrm{~km}$-wide valley in central Spitsbergen, that was deglaciated
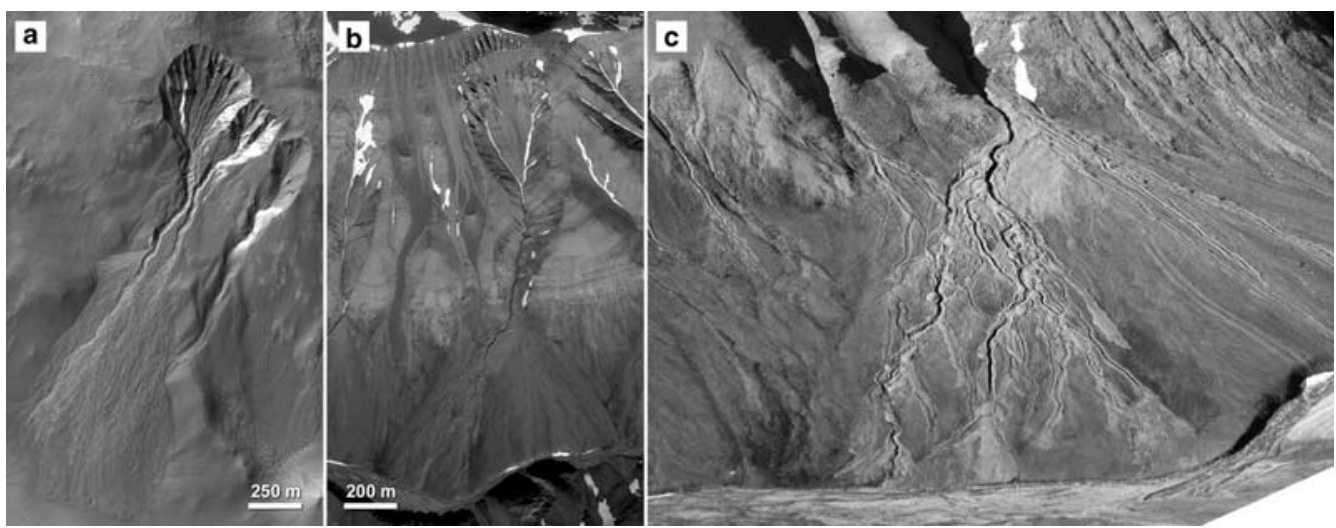

Fig. 3. Gullies and fans on Mars and Svalbard. (a) Gully in Martian crater at $38.5^{\circ} \mathrm{S}, 319.8^{\circ} \mathrm{E}$ (HiRISE PSP_006888_1410). (b) Gully and debris-flow fan in Hannaskogdalen, Svalbard. Note the similarity in morphology and scale between the two systems. (c) Close-up field photograph (taken from the opposite mountain) of the fan surface shown in (b). Note the morphological indicators of debris flows, such as large lateral levees and flow tongues. Image credit: NASA/JPL/UofA, DLR and Univ. Münster/Mike Zanetti. 

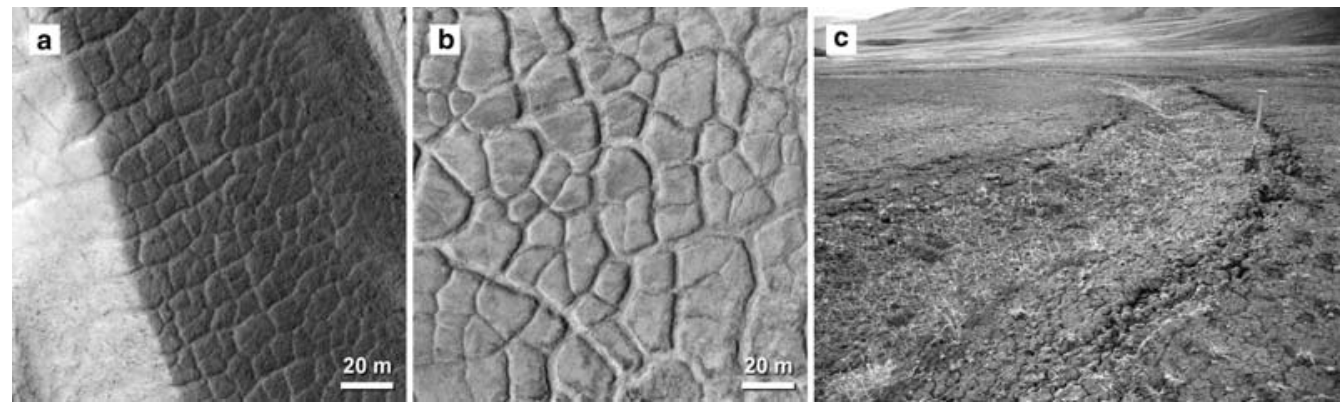

Fig. 4. Polygons on Mars and Svalbard. (a) Oriented-orthogonal polygons pattern on a ridge between two gullies on the northern wall of Hale Crater, Mars. The polygons have high centres and diameters between about 5 and $10 \mathrm{~m}$ (HiRISE image PSP_004072_1845; near 34.6 ${ }^{\circ} \mathrm{S}, 323.1^{\circ} \mathrm{E}$ ). (b) High-centre orthogonal polygons in central Adventdalen (HRSC-AX image). The polygons have high centres, and diameters between approximately 10 and $20 \mathrm{~m}$. A trough that is typical for this type of polygon is shown in panel (c). (c) Trough between high-centre polygons in central Adventdalen. Note the fractured and degraded appearance of the trough shoulders. Spade for scale. Image credit: NASA/JPL/UofA, DLR and AWI/Mathias Ulrich.
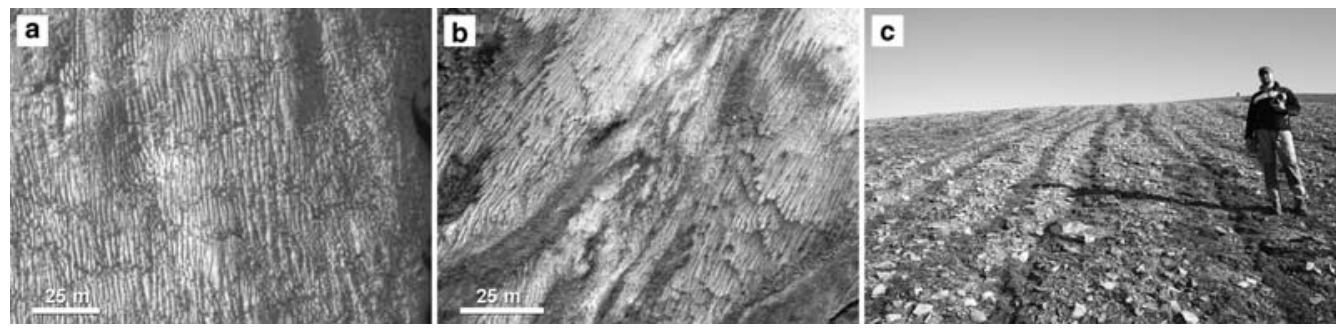

Fig. 5. Comparison between alternating bright and dark stripes on Mars and sorted stripes on Svalbard. (a) Alternating dark and bright stripes near gullies on the inner wall of a Martian impact crater (HiRISE image PSP_001684_1410; near $38.9^{\circ} \mathrm{S}, 196.0^{\circ} \mathrm{E}$ ). The orientation of the stripes is approximately downslope. (b) Sorted stripes on the western slopes of the Hiorthfjellet massif (east of Adventfjorden, Spitsbergen). Note the striking similarity in scale between (a) and (b). (c) Sorted stripes in Adventdalen (Spitsbergen). Coarser and slightly elevated unvegetated stripes alternate with finer-grained and vegetated stripes (person for scale). Image credit: NASA/JPL/UofA, DLR and DLR/Ernst Hauber.
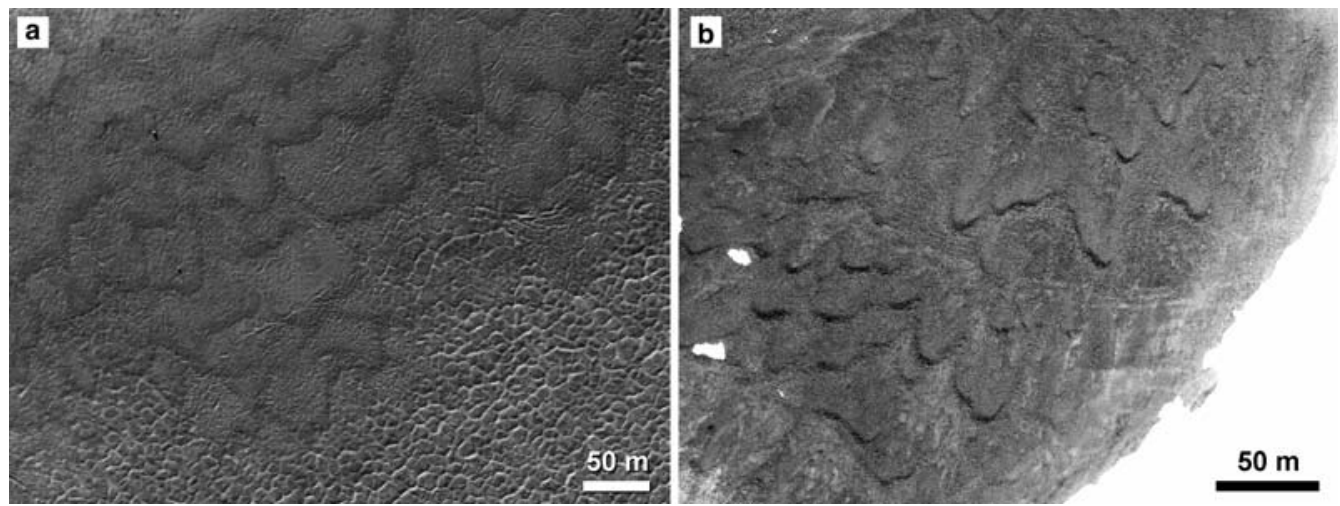

Fig. 6. Comparison between lobate structures on Martian slopes and solifluction features on Svalbard. (a) Lobate features on the inner wall of an impact crater on Mars (near $71.9^{\circ} \mathrm{N}, 344.5^{\circ} \mathrm{E}$; HiRISE PSP_010077_2520). The morphology is identical to that of lobate solifluction sheets (cf. Ballantyne \& Harris 1994, fig. 11.1). Although this particular example is on the wall of a crater in high latitudes, it is expected that such features might also be found in mid-latitude craters. (b) Solifluction lobes on the slopes of Louisfjellet (central Spitsbergen, Svalbard). Note the striking similarity in scale and morphology between (a) and (b). Image credit: NASA/JPL/UofA and DLR. 

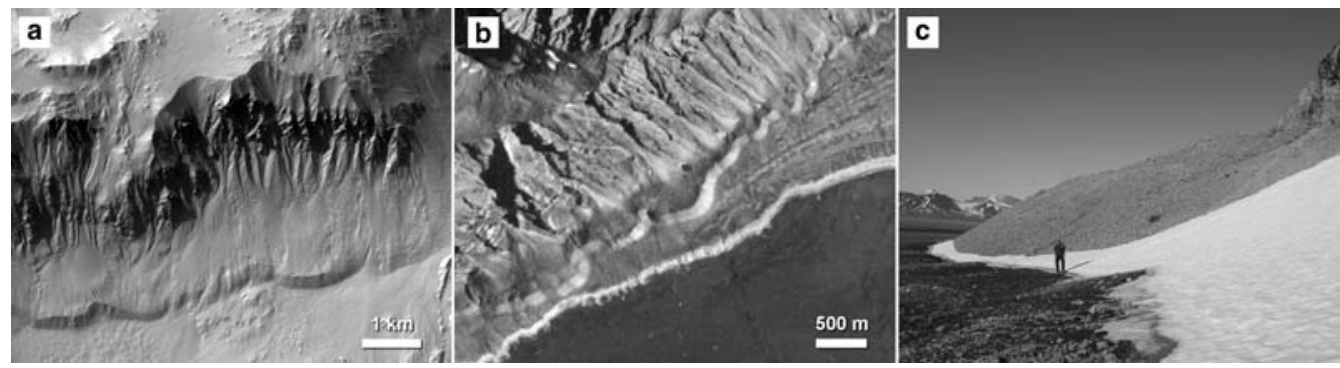

Fig. 7. Possible protalus ramparts on Mars (left) and Svalbard (right). (a) Protalus lobe-like structures at the base of a large scarp on the northern wall of Hale Crater (CTX image P15_006756_1454; near 34.6 ${ }^{\circ} \mathrm{S}, 323.1^{\circ} \mathrm{E}$; north is up). The steep front is characterized by polygons (see Reiss et al. 2009; their fig. 10b, c). (b) Protalus lobes on the northern tip of Prins Karls Forland, Svalbard (see Berthling et al. 1998), at the western foot of the Fuglehukfjellet massif (aerial photograph S704128, Norsk Polarinstitutt, Oslo, Norway; from André (1994); north is towards the left). (c) Close-up image of a protalus rampart at Stuphallet, Brøgger Peninsula (see person for scale). The surface of the steep front consists of very coarse blocks (diameters of up to tens of centimetres). Image credit: NASA/JPL/MSSS and Univ. Münster/Dennis Reiss.

about 10000 years ago (Mangerud et al. 1992). The valley hosts a large number of periglacial landforms, both on the valley flanks and on the valley floor. The mountain massifs and the upper parts of many valleys are still partly covered by polythermal or cold-based glaciers, which can be partly debris-covered (Tolgensbakk et al. 2000). Distinctive end moraines, which may be ice-cored (Lukas et al. 2005), mark the former larger extent of the glaciers. Some tongue-shaped rock glaciers are perched in cirques and broad alcoves (Isaksen et al. 2000; Ødegård et al. 2003). Protalus ramparts, defined as 'ridges or ramps of debris formed at the downslope margin of a snowbed or firn field' (Shakesby 1997, p. 395), are well developed on the foot of high cliffs on the Brøgger Peninsula (Fig. 7b, c). Rock fall is frequent from the steep cliffs that mark the flat-topped summits of the mountains (André 1995). The flanks of the massifs bordering the valley are dissected by numerous gullies (Fig. 3b, c), which are the transport pathways for debris flows. Debris flows can reach volumes of $50-500 \mathrm{~m}^{3}$ in the Longyearbyen Valley (Larsson 1982), and their recurrence interval is $80-500$ years (André 1990). Between the gullies, many slopes display evidence of solifluction (Fig. 6b) and sorting processes (sorted and non-sorted nets and stripes: Fig. 5b, c) (Sørbel \& Tolgensbakk 2002). The debris flows build up fans, characterized by channels with lateral levees, flow tongues and coarse sediment (for a description of an alluvial fan in a permafrost region see Catto 1993). Where fans extend to the shore of the estuary at the mouth of Adventdalen, they can form an arctic fan delta (Lønne \& Nemec 2004). In the inland, debris-flow fans at the downstream-end of the gullies coalesce
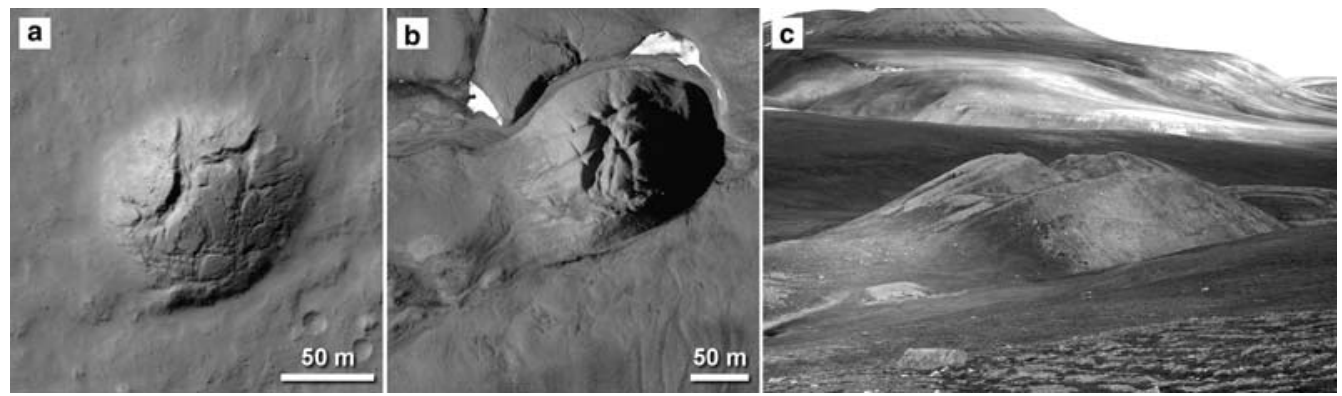

Fig. 8. Comparison between a fractured mound on Mars and pingo on Svalbard. (a) Fractured mound on the floor of a crater in the southern hemisphere (detail of HiRISE image PSP_007533_1420; near $37.9^{\circ} \mathrm{S}, 347.2^{\circ} \mathrm{E}$ : see Dundas \& McEwen 2010). (b) Pingo in upper Eskerdalen (central Spitsbergen) with fractures on its top. HRSC-AX image, acquired in July 2008. Note the morphological similarity to the shallow fractured mound shown in (a). (c) Field photograph of pingo shown in (b). North is up in panels (a) and (b). View towards the NE in panel (c). Image credit: NASA/JPL/UofA, DLR and DLR/Ernst Hauber. 
along the valley to form bajadas. The valley floor is occupied by the large braided river, Adventelva, which often cuts the toes of the fans. Several opensystem (hydraulic) pingos are located near the fans on the valley floor (Fig. 8b, c) (Liestøl 1976; Yoshikawa 1993; Yoshikawa \& Harada 1995). River terraces are overprinted by thermal-contraction cracks that form widespread nets of ice-wedge polygons (Fig. 4b, c) (Christiansen 2005). Most of the landforms on the valley flanks can be considered to be part of an ice-debris transport system, where mass wasting takes place both by steady-state processes (small-scale rockfall, avalanches, glacial and fluvial transport and solifluction) and by more extreme short-lived processes (large-scale rockfall, landslides, debris flows) (Haeberli 1985). Figure 9 demonstrates the spatial arrangement of the landforms in Adventdalen in an idealized sketch, and Figure 10 shows a three-dimensional perspective view of the Hiorthfjellet massif exhibiting some of the features in their real setting.

\section{Discussion}

The above comparisons suggest that periglacial processes might have operated in Martian mid-latitude craters. However, the exact nature, intensity and sequence of these processes are unclear. We present three different models that outline in a qualitative way some possible scenarios of how midlatitude craters were shaped in the recent Martian history by processes involving water ice and, to a lesser degree, liquid water. It is important to note that these models are not thought to be mutually exclusive, nor do they necessarily include all processes that operated on Mars. Instead, they are suggested as examples of how planetary landform analysis guided by terrestrial knowledge can yield improved insight into the evolution of complex landscapes.

The premise of the models is that during higher obliquity water ice is driven from the poles towards lower latitudes where it is precipitated as snow. During periods of lower obliquities, the precipitated snow would sublime or melt, and water vapour would be redistributed at higher latitudes. This basic pattern of volatile transport through the atmosphere as a function of obliquity has been modelled with GCM (Mischna et al. 2003; Levrard et al. 2004; Forget et al. 2006; Madeleine et al. 2009), and the modelling results successfully predict ice accumulation in places where, indeed, an increased frequency of possible glacial landforms have been glacial domain

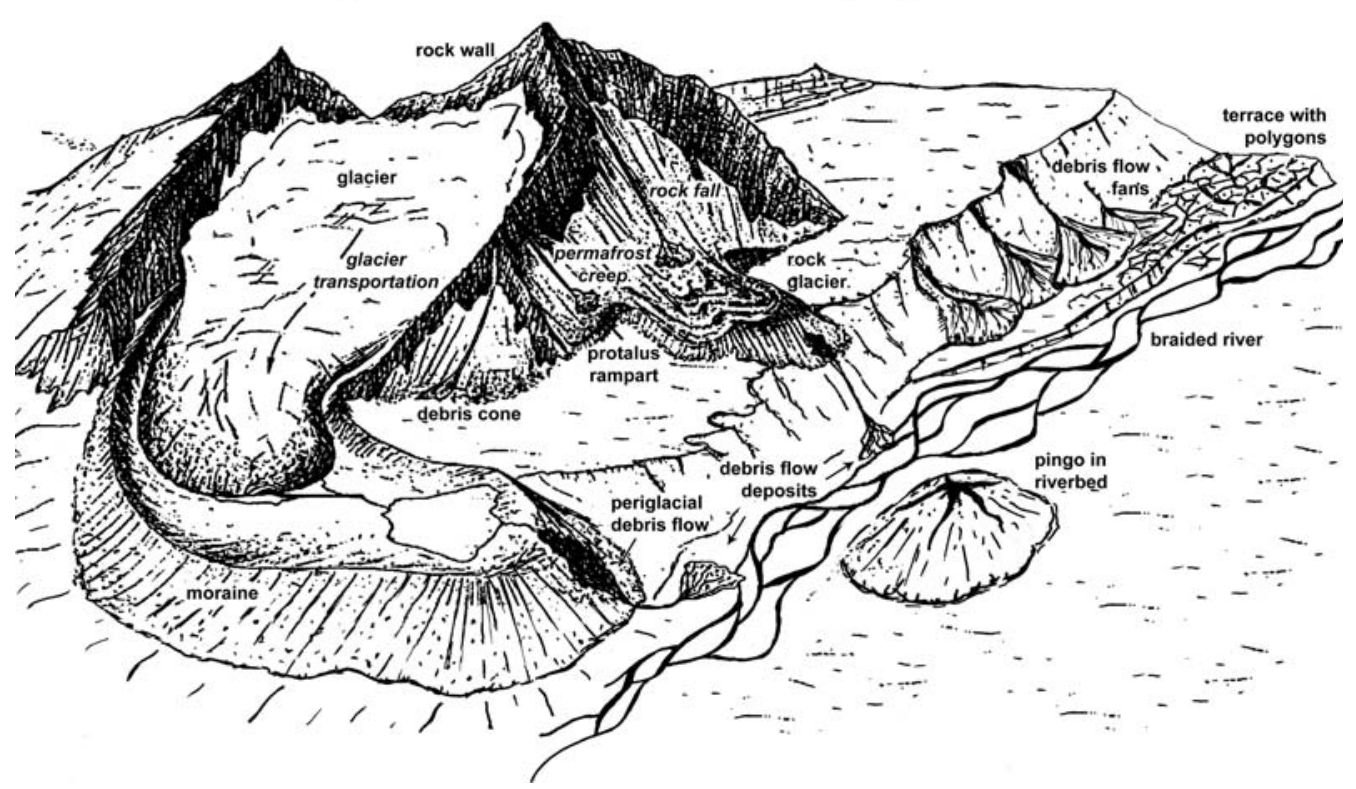

Fig. 9. Ensemble of glacial and periglacial landforms observed in Adventdalen (central Spitsbergen, Svalbard; modified from Haeberli, 1985, fig. 1). The qualitative sketch is not meant to represent the real situation in Adventdalen, but to illustrate the spatial arrangement of the landforms. Morphologically similar landforms have been observed in Martian mid-latitudes craters, often in comparably close spatial proximity. The unique advantage of such terrestrial analogues is their potential to provide constraints in the interpretation of planetary surface morphologies. 


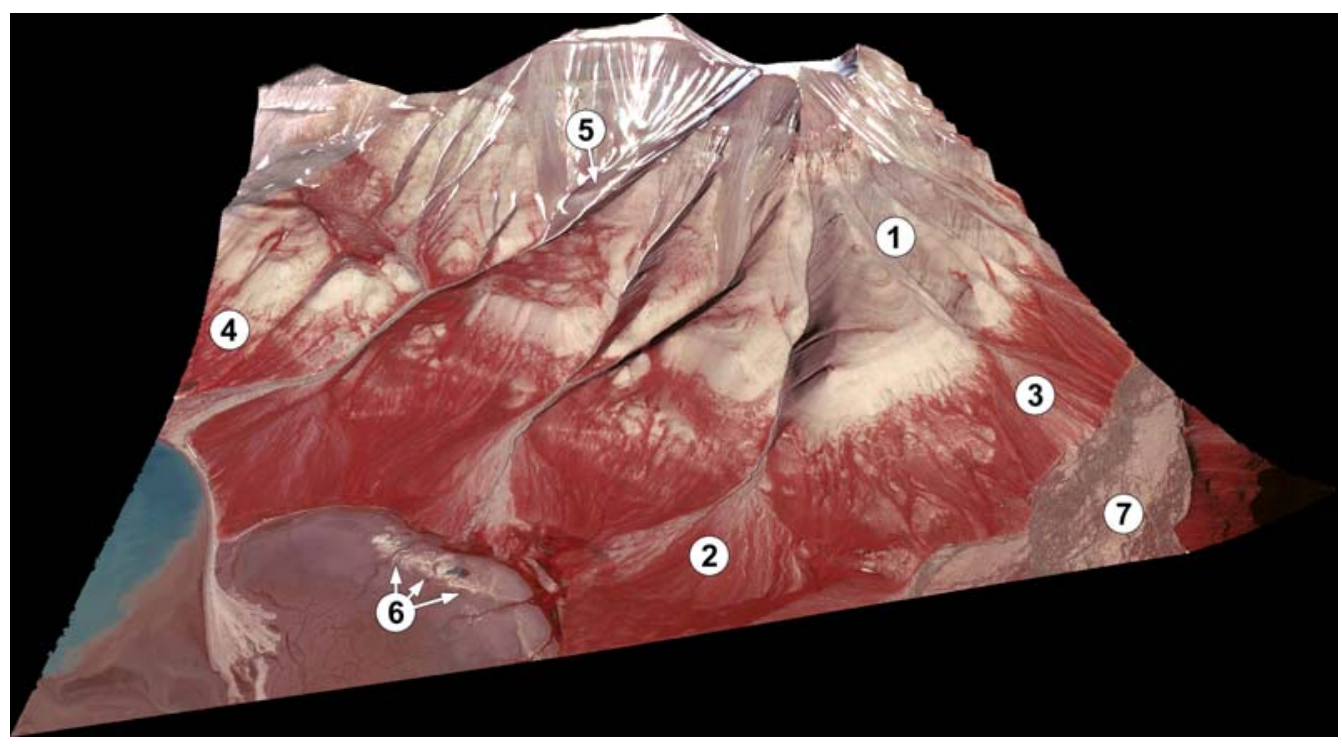

Fig. 10. Example of the close spatial proximity of glacial and periglacial landforms on Svalbard. The scene (width c. $3.7 \mathrm{~km}$; north is towards the background) was computed from HRSC-AX false-colour stereo images and shows the Hiorthfjellet mountain massif on the northern side of Adventfjord. Numbers refer to specific landforms: 1, gullies; 2, alluvial fan; 3, debris-flow fans merging along the valley wall into a bajada; 4, slope stripes; 5, rock glacier; 6, pingo; 7 , braided river. All of these landforms with the exception of the braided river have close morphological analogues in Martian mid-latitude craters. Image credit: DLR.

observed (e.g. east of the Hellas Basin, west of the Tharsis Montes and at the Deuteronilus Mensae region). If this premise is accepted, it implies that the pattern of deposition and degradation of snow and the associated periglacial processes operate in cycles, as the obliquity varies cyclically. One of such cycles is discussed in the following for each of the scenarios.

Following the scheme of landscape evolution proposed by Morgenstern et al. (2007) for the lowlands of Utopia Planitia, the initial process in the cycle of deposition and degradation is the subaerial deposition of a volatile-rich mantle consisting of a layered mixture of dust and snow. Martian dust is suggested to originate from volcanic sources, meteoritic impact and rock erosion, and is redistributed by global dust storms (Kahn et al. 1992). The dust particles act as condensation nuclei for water ice $\left(\mathrm{H}_{2} \mathrm{O}\right.$-ice: e.g. Gooding 1986). The dusty snow mantle would be thicker at the pole-facing wall, but would also cover the crater interior and smaller crater therein. This stage is common to all three scenarios (Fig. 11a-c, stage I). Such a mantling deposit had already been suggested on the basis of Mariner 9 data (Soderblom et al. 1973), and was later revealed in detail by high-resolution topography (Kreslavsky \& Head 2000) and images (Mustard et al. 2001). This mantling layer has a thickness of the order of tens of metres in lowlands
(Morgenstern et al. 2007), but it is not clear how much of this thickness is deposited during one obliquity cycle. The microclimatic conditions at polefacing (inner) walls of craters are such that ice is preferentially accumulated and preserved in these locations, that is, they function as cold traps for atmospheric water ice (Hecht 2002; Schorghofer \& Edgett 2006; Head et al. 2008).

\section{The 'dry' scenario}

Over time, the accumulated snowpack would increase in thickness and eventually the lower portions would transform into glacier ice (Fig. 11a, stage II). This glacier would probably contain a significant amount of dust (and perhaps wind-blown sand, but no or very few rock fragments) and we tentatively suggest the term 'dust glacier'. The planview shape of such glaciers would typically be tongue-shaped (length $>$ width), as it is commonly observed on Earth (for a comparison between these shapes on Mars and Earth, see Arfstrom \& Hartmann 2005, their fig. 2). If it were cold enough, this glacier would freeze onto the underlying crater wall and be a cold-based glacier, as has previously been suggested for Mars (Head \& Marchant 2003). A cold-based glacier would cause little or no erosion of the underlying crater wall and, therefore, the slope of this wall might remain 
(a)

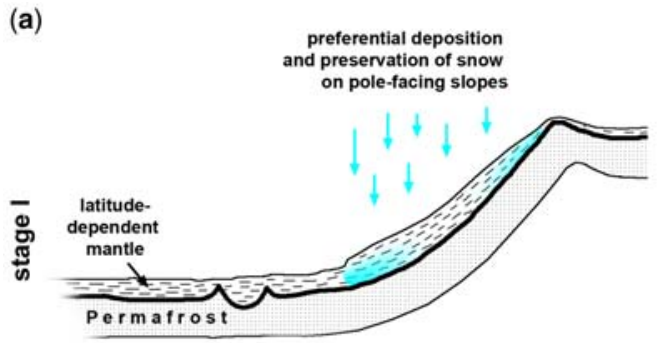

(b)

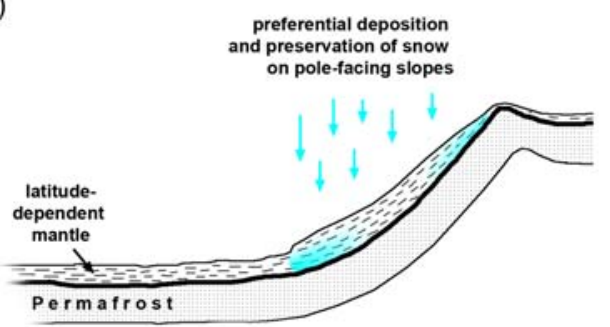

(c)

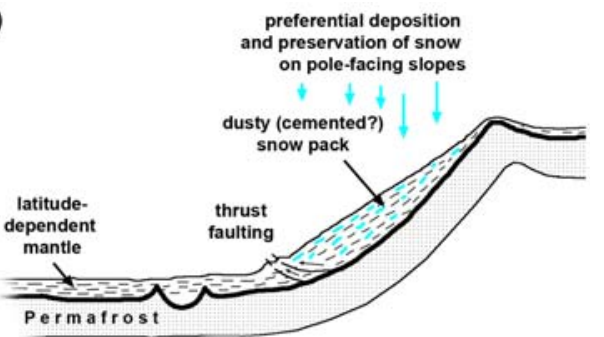

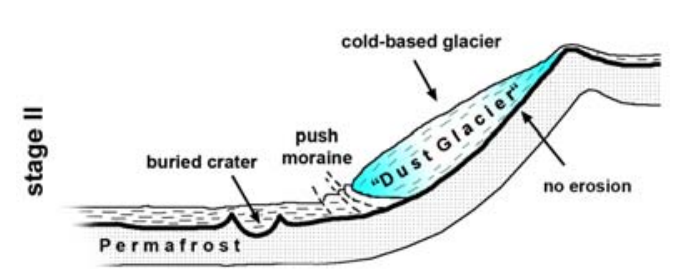
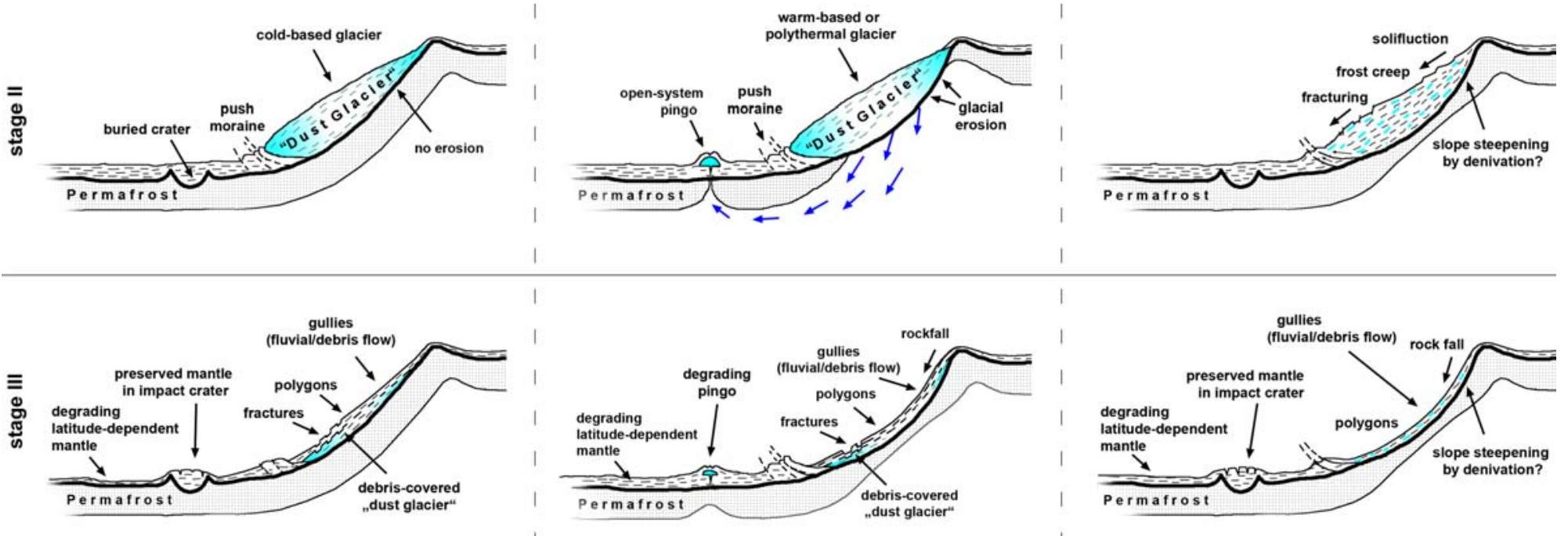

Fig. 11. Qualitative scenarios of landscape evolution in Martian mid-latitude craters. See the text for details. 
more or less unchanged. At the downslope termination of the glacier, thrust or push moraines could develop (e.g. Berman et al. 2005) because even if there was no basal sliding of the glacier it would deform internally and move downslope. The presence of push moraines in front of cold-based glaciers has been well documented on Earth (e.g. Haeberli 1979), where push moraines are the morphological result of permafrost deformation. These moraines would be piled up to form ridges, which might contain some ice. In some cases, a lobate body might form at the base of the crater wall that has a width larger than its length (Fig. 7a). This class of flow feature exhibits a striking large-scale similarity to protalus ramparts on Svalbard (Fig. 7b). The spatial proximity of 'dust glaciers' (ice-cored), moraines and permafrost features, such as protalus ramparts, would not be surprising because it was suggested that these landforms might be part of a morphological and developmental continuum (Shakesby et al. 1987). At smaller scales of observation, however, significant differences become obvious between the Martian and terrestrial features shown in Figure 7. The steep distal front of the Martian flow feature is overprinted by polygons (cf. Reiss et al. 2009, fig. 10), which are likely to have been developed as thermal contraction cracks in fine-grained material. In contrast, the distal fronts of the protalus ramparts on Svalbard consist of coarse, decimetre-sized rocks derived from steep cliffs and mountain slopes. The difference is easily explained, however, if the relief above the features is taken into account. On Svalbard, the slopes are steep and frequent mass wasting delivers copious amounts of coarse particles, which form the rocky part of the rock glacier. Conversely, the lower slopes of large and old craters on Mars (such as Hale Crater, in the example of Fig. 7a) are much gentler, and the material being mixed with ice to form the protalus rampart-like feature would be fine-grained airborne dust. On the surface of such a body, it would be reasonable to expect the formation of sublimation polygons.

After the obliquity decreases, the ice would slowly become unstable and begin to sublimate. A lag deposit of dust and sand would form at the top of the glacier, decreasing the rate of sublimation (Mellon \& Jakosky 1993; Chevrier et al. 2007). Internally, the glacier might still be deformed. If the lag deposit has some cohesion (e.g. from cementation), the ongoing internal deformation of the glacier body might crack the lag deposit and form tension fractures, normal faults and grabens paralleling the topographical contours. When sublimation would have removed most of the ice, a thick and very fine-grained lag deposit (dominated by dust-sized particles) would remain above a thinned body of buried glacier ice. At the same time, the mantling deposit in the crater interior would also degrade and become thinner. Where this mantling filled a smaller impact crater, it might be preferentially preserved, leaving a high-standing mound of the mantling that could develop fractures at its top. As Dundas \& McEwen (2010) have already discussed, such a fractured mound could easily be misinterpreted as a pingo (Fig. 11a, stage III). Thermal contraction polygons could develop in the sublimation lag. By analogy to the McMurdo Dry Valleys in the Antarctica, these polygons could be sublimation polygons (Marchant et al. 2002), as suggested for Mars by Levy et al. $(2009 b)$. It has to be noted, however, that the exact nature of the polygons (ice-wedge polygons, sandwedge polygons or sublimation polygons) remains an open question as the morphology alone does not allow for an unambiguous identification of either of these forms (e.g. van Gasselt et al. 2005). For example, degraded ice-wedge polygons in Adventdalen (Fig. 4b, c) display a morphology that can hardly be distinguished from sublimation polygons in remote-sensing imagery. With continual degradation, the volume of the remaining ice would be so small that scalloped depressions would form between the thrust moraines, left behind as arcuate ridges, and the remaining lag deposit on the crater walls (Fig. 11a, stage III). Remnant thicker patches of near-surface ground ice (Costard et al. 2002) or snow perched high in alcoves on the crater rim (Head et al. 2008) might finally melt (Hecht 2002; Kossacki \& Markiewicz 2004). The meltwater could run off surficially and initiate fluvial transport and downstream deposition, where a resulting alluvial fan would form (Fig. 11a, stage III). Alternatively, the meltwater could infiltrate into the lag deposit, saturate it, increase the pore pressure and thus reduce its shear strength, which would increase the susceptibility of the material to gravity-driven failure and debris flows (e.g. Iverson et al. 1997). The degree of saturation is commonly increased if a low-permeability layer in the subsurface is present, which leads to the transient perching of the water table (Reid et al. 1988), and the frozen underground would be such a hydrological barrier. Another factor favouring the development of debris flows in this setting on Mars is the small grain size of the lag deposit because clay-sized material is required to maintain the high pore pressures needed during the flow (Iverson 1997). This mechanism of debris-flow initiation has also been proposed by Lanza et al. (2010). Unambiguous evidence for debris or mud flows on Mars has, indeed, been found by Levy et al. (2010). The debris flows and the fluvial processes would form a downstream fan, as is typical for Earth. The fans have been dated by crater counting and have ages 
of the order of $10^{5}-10^{6}$ years (Reiss et al. 2004; Schon et al. 2009a). In the 'dry' model, a transition takes place from glacial to periglacial processes, and the formation of gullies and fans from and on the lag deposit would be the final stage (Dickson \& Head 2009).

\section{The 'wet' scenario}

The second scenario starts as the 'dry' one, except that a warm-based or polythermal 'dust glacier' would form. This glacier would experience basal melting and, therefore, the ice and subglacial meltwater would erode and steepen the crater wall (Fig. 11b, stage II). Another difference to the first scenario would be the extent of the permafrost layer. Beneath the warm-based glacier, the permafrost would disappear and liquid water generated by the basal melting of the glacier would infiltrate into the substrate. A similar scheme was proposed by Carr \& Head (2003) and Fassett \& Head (2006). The groundwater would migrate down towards the interior of the crater. In the subsurface of the crater floor, beyond the extent of the
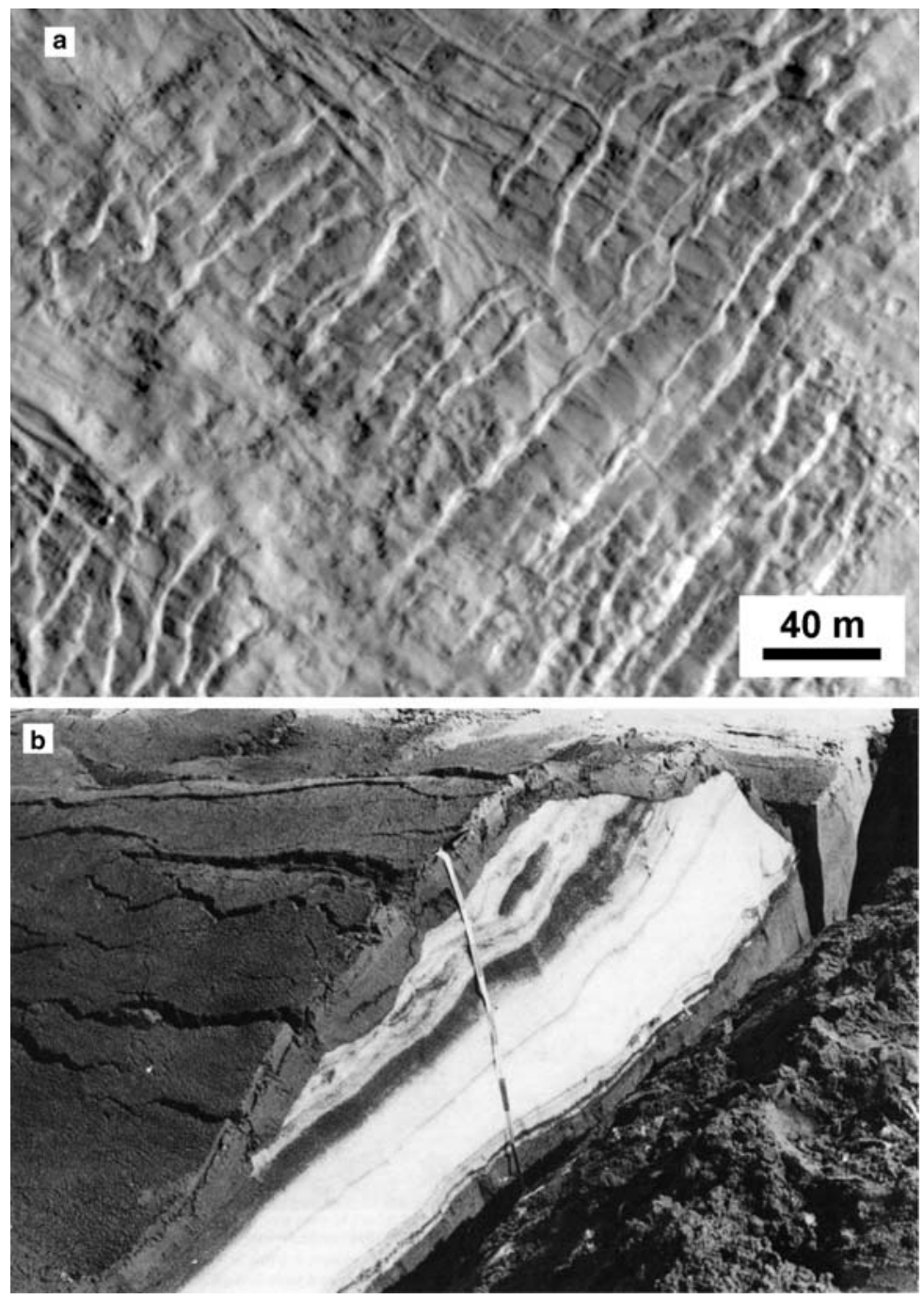

Fig. 12. (a) Extensional features (normal faults and grabens) trending normal to the topographical gradient of the inner wall of an impact crater in the northern mid-latitudes (near 39.5 $\mathrm{N}, 105.4^{\circ} \mathrm{E}$; detail of HiRISE PSP_001357_2200, north is up). (b) Niveo-aeolian sediment at the lee (slip) side of a transverse dune in the Great Kobuk Sand Dunes (NW Alaska, USA; from Koster (1988), photograph by J. Dijkmans). Image credit: NASA/JPL/UofA and J. Dijkmans. 
glacier, there would be an impermeable permafrost layer above the groundwater, and the hydraulic head would pressurize the groundwater. At weak spots in the crater floor, which would be abundant owing to the fracturing that was created at the impact, this groundwater could ascend as artesian water. Reaching the near surface, it would freeze and build a growing ice core. With time, a mound consisting of this ice core and some overlying mantle deposit would rise. This is how hydraulic (open-system) pingos grow on Earth, except that they do not form in craters, but rather in valleys where the hydraulic head has its source in nearby mountains (Müller 1959; Worsley \& Gurney 1996; Mackay 1998). The pingos in the study area in Spitsbergen are also thought to form by this mechanism (Liestøl 1976, fig. 2). If the same process applies to Mars, it would represent an example of glacierpermafrost interaction, which is also considered to be an important factor in landform evolution on Svalbard (Etzelmüller \& Hagen 2005). The steepening of the crater wall by glacial erosion would increase the probability for rockfall, which was suggested as a triggering mechanism for debris flows on Earth if the other requirements (saturated soil, positive pore pressure) are met (Hsu 1975; Johnson 1995). Apart from these differences, this 'wet' scenario would otherwise be very similar to the 'dry' scenario, and glacial processes (including surficial meltwater production and runoff: Fassett et al. 2010) would be followed by the formation of periglacial landforms (polygons, solifluction lobes, rock glaciers and pingos) and, finally, paraglacial processes (avalanches, rock falls, debris flows, chemical denudation, mechanical fluvial denudation and surface movements/creep) (Fig. 11b, stage III).

\section{The 'snow' scenario}

A thick snowpack might form instead of a glacier in the 'snow' scenario (Fig. 11c, stage I). The transition of snow (or rather firn) to glacier ice is defined by density and starts at approximately $830 \mathrm{~kg} \mathrm{~m}^{-3}$, where interconnecting air passages between ice grains become sealed off (Paterson 1994) and reach a final value of $917 \mathrm{~kg} \mathrm{~m}^{-3}$ (Knight 1999, table 3.3; for an extended discussion of ice metamorphism, firnification and ice formation see Shumskii 1964, pp. 240-303). While it is known that many factors (e.g. vapour transport, and the diurnal and seasonal temperature variations) control the snow densification on Mars (Arthern et al. 2000), a clear difference between Earth and Mars is the rate of gravity-driven snow densification (sintering). Other factors being equal, the transition from snow (or rather firn) to glacier ice should, therefore, occur on Mars at a greater depth than on Earth (the Martian gravitational acceleration at its surface is about $38 \%$ of that on the Earth's surface). Typical values for this depth on Earth are approximately $10-20 \mathrm{~m}$ in temperate areas and much less than $50 \mathrm{~m}$ in cold continental areas (e.g. Shumskii 1964, p. 275). The timescales of this transformation are also vastly different, depending on the climate. In cold and dry climates, such as in Antarctica, the transformation may require up to 2500 years (Paterson 1994, table 2.2), whereas it can be as short as only a few years in
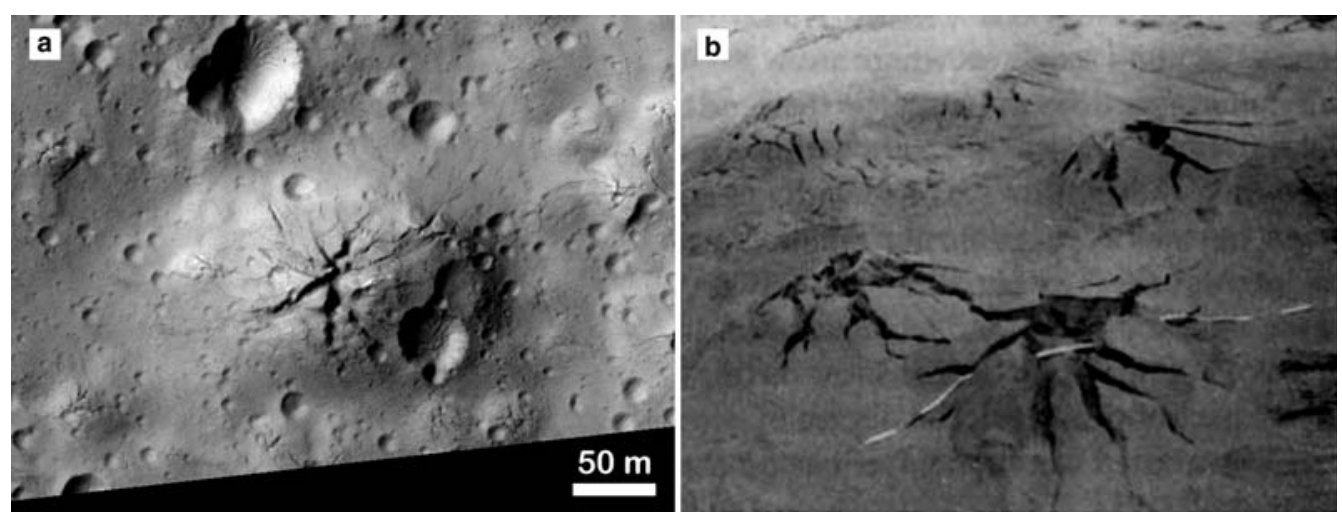

Fig. 13. Comparison between fractured mound on Mars and niveo-eolian features on Earth. (a) Mound with radial fractures on the floor of an impact crater in the southern mid-latitudes. The surface of the mound is superposed by several round depressions that might be due to collapse and/or impact cratering (near $33.6^{\circ} \mathrm{S}, 124^{\circ} \mathrm{E}$; detail of HiRISE PSP_002135_1460; north is up). (b) Snow hummock with radial tensional cracks on the Great Kobuk Sand Dunes (Alaska, USA; from Koster \& Dijkmans 1988). The hummock is a denivation form that developed in niveo-eolian beds. Note the morphological similarity to (a), but also note the large difference in scale (these hummocks are only a few decimetres to $1 \mathrm{~m}$ wide). See the text for details. Image credit: NASA/JPL/UofA and J. Dijkmans. 

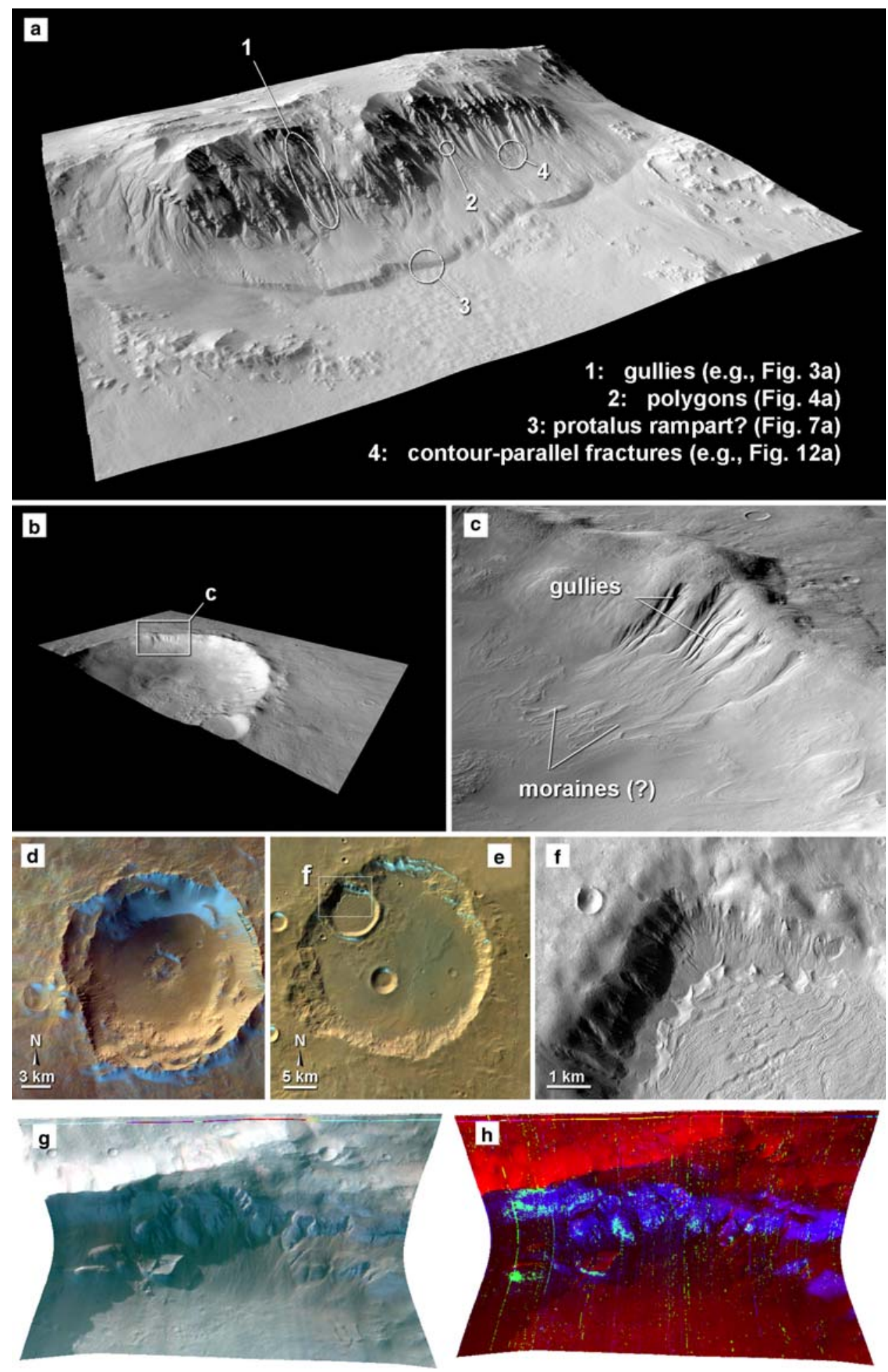

Fig. 14. 
more temperate regions such as in NW Canada. In summary, it can be expected that it takes longer in a very cold and, presumably, rather dry climate on Mars to transform snow to firn and finally to ice than on Earth. This should be true even for recent periods of higher obliquity. Similarly, one might expect snowpacks on Mars to reach larger thicknesses than on Earth before they transform to glacier ice. Based on these qualitative considerations, it seems likely that in many cases the accumulation of snow did not result in a glacier, but in a thick snowpack with intercalated layers of dust and, perhaps, wind-blown sand (cf. Williams et al. 2008, fig. 3). The snow scenario is perfectly in agreement with an interpretation of the features shown in Figure $7 \mathrm{a}$ as protalus ramparts because such landforms on Earth are evidence of snow accumulation. Sublimation of snow would, again, favour the formation of a lag deposit on top of the snowpack. The slow downward creep (Perron et al. 2003) in combination with compaction and sublimation of snow could induce fracturing of the overlying lag deposit (Fig. 12a). A terrestrial analogue for this process was described by Koster (1988), who investigated niveo-aeolian forms in Alaska. He found that denivation of sand-covered snow on dunes can produce deformational structures such as tensional cracks and compressional features (Fig. 12b) (see also Dijkmans 1990, fig. 3b), which are morphologically similar to the contour-parallel fractures and grabens commonly seen on the lower slopes of mantling deposits and fans on Mars (cf. Fig. 12a). The creep of the snowpack might also pile up some permafrost material at the base, analogous to the moraines in the dry and wet scenarios (Fig. 11c, stage II).
The melting of a dusty snowpack has long been recognized as a potential source of liquid water on Mars (Clow 1987), and more recent studies confirmed this possibility (Williams et al. 2008). While the results of Williams et al. (2008) apply only to periods of obliquity higher than that of today, Möhlmann (2010) emphasized the outcome of the 'solid-state greenhouse effect' in generating liquid water in snowpacks and concluded that, even in the current climate of Mars, liquid water can be produced. Williams et al. (2009) modelled snow melt at mid-latitudes on Mars and found that enough meltwater can be generated to produce gullies, an idea that had been previously suggested by Christensen (2003). Whenever the snow melting occurred exactly, it would be a viable process to provide the required liquid water for gully and fan formation in the 'snow' scenario. If an active layer existed in the past (Kreslavsky et al. 2008), solifluction might occur in the form of frost creep or gelifluction, although the period of the freeze-thaw cycles is difficult to constrain (day-night or seasonal cycles). Fractured mounds would form as erosional forms, not as pingos. Where all the snow in the surrounding has decreased in height or disappeared, snow hummocks would remain, consisting of residual snow patches or ridges (Koster \& Dijkmans 1988). When the tops of these denivation forms are broken up into radial patterns, they display a strikingly similar morphology to Martian fractured mounds (Fig. 13). There is a huge difference in scale between the two types of fractured mounds shown in Figure 13, but the principle should work for the larger fractured mounds on Mars as well. The other landforms would form very similarly as in

Fig. 14. (Continued) Assemblages of possible periglacial landforms and water ice on Martian pole-facing crater walls. (a) Part of south-facing inner wall of Hale Crater, displaying several landforms that resemble periglacial landforms on Svalbard. CTX image P15_006756_1454 superposed on HRSC DEM (HRSC h0533_0000). View is towards the NE, no vertical exaggeration, image width is about $12 \mathrm{~km}$. (b) Perspective view of a crater in the southern mid-latitudes (at $\left.45.66^{\circ} \mathrm{S}, 238.11^{\circ} \mathrm{E}\right)$. CTX image B05_011519_1341 superposed on HRSC DEM (HRSC h0424_0000). View is towards the NE, no vertical exaggeration, crater diameter is $26 \mathrm{~km}$. (c) Slightly rotated detail of the scene shown in (b), with gullies and possible moraines at the downward termination of the inferred location of former glaciers (view towards the north). (d) Snow and frost on pole-facing slopes (crater centre at $46.05^{\circ} \mathrm{S}, 183.85^{\circ} \mathrm{E}$; detail of HRSC h8569_0000; image acquired during the southern winter at solar longitude $\left.\left(\mathrm{L}_{\mathrm{S}}\right) 147.8^{\circ}\right)$. The bright material is likely to be water ice, as it was found by the Compact Reconnaissance Imaging Spectrometer (CRISM) at a similar latitude during the same season (see panels g and h). (e) Another example of snow and frost preferentially accumulated on pole-facing slopes (crater centre at $39.6^{\circ} \mathrm{S}, 158.32^{\circ} \mathrm{E}$; detail of HRSC $\mathrm{h} 8527 \_0000$; image acquired during the southern winter at $\mathrm{L}_{\mathrm{S}} 141.6^{\circ}$ ). The white box marks the location of panel (f) and corresponds to an area where bright material accumulated on the inner wall of a smaller impact crater. (f) Detail of the previous image. The area of snow accumulation corresponds exactly to sites where gullies, fans and moraine-like landforms are observed (detail of CTX B05_011746_1401). (g) CRISM false-colour image of a crater rim in Terra Sirenum (near $38.9^{\circ} \mathrm{S}, 195.9^{\circ} \mathrm{E}$ ). Frost is characterized by a 'bluer' colour than the rock and soil. The image was taken during the Martian winter at $\mathrm{L}_{\mathrm{S}} 140.6^{\circ}$ (image source: NASA

PlanetaryPhotojournal, \#PIA09101). (h) Same scene as (g), with the colour indicating the depths of absorption bands of $\mathrm{H}_{2} \mathrm{O}$-frost at $1.50 \mu \mathrm{m}$ (blue) and $\mathrm{CO}_{2}$-frost at $1.45 \mu \mathrm{m}$ (green). While $\mathrm{CO}_{2}$-frost occurs only at the coldest, most shaded areas, water ice is more widespread and occurs on slopes incised by many gullies (image source: NASA

PlanetaryPhotojournal, \#PIA09101; see also Vincendon et al. 2009). Image credit: ESA/DLR/FUB, NASA/JPL/ MSSS and NASA/JPI/JHUAPL. 
the other scenarios (Fig. 11c, stage III). An important aspect of this scenario and the associated snow melting would be intensified chemical weathering, the role of which has been underestimated in the past even on Earth (Thorn 1988).

\section{Conclusions}

Despite significant differences in the climates of Mars and Svalbard, a suite of very analogous landforms has developed, although perhaps over enormously different timescales. Attempts to reconstruct palaeo-climates on Mars have to take into account the fact that different processes acting in different environments can produce similar results (equifinality). The integrated analysis of landscapes can reduce such ambiguities.

The landform inventory associated with polefacing inner walls of impact craters in the Martian mid-latitudes (Fig. 14) suggests the geologically recent action and interaction of glacial and periglacial processes. Based on terrestrial analogue landforms in similarly close spatial proximity on Svalbard, three scenarios of sequential landscape evolution are presented for Mars. All scenarios start with initial snowfall and the deposition of a dusty snowpack, and they all end with recent gully and fan formation. These scenarios are qualitative in the sense that none of them is expected to exactly represent the real situation on Mars. In fact, the scenarios are not mutually exclusive, and mixed cases (e.g. the dry and the snow scenarios) are very plausible. Dependent on latitude and insolation, some craters might have been shaped by the dry scenario, while craters at other latitudes might have been shaped by the wet scenario. The different scenarios also have different implications for the interpretation of certain landforms. For example, fractured mounds are unlikely to be open-system pingos in the dry scenario because that does not predict liquid water in the subsurface, a prerequisite for the growth of hydraulic pingos. However, basal melting of snow in the snow scenario could lead to infiltration of liquid water into the subsurface and the formation of a hydraulic pingo as in the wet scenario.

The landscape evolution proposed here would be controlled by obliquity and/or orbital parameters such as eccentricity or the position of perihelion, and is therefore assumed to be cyclic. Several successive episodes of deposition and removal have already been suggested by, for example, Kreslavsky \& Head (2002), Schon et al. (2009b) and Morgan et al. (2010). Processes implying an active layer might have operated in the past, although an active layer does not exist today (Kreslavsky et al. 2008). It is thus important to realize that the Martian mid-latitude morphologies do not represent a stable situation over long periods. Instead, this is a dynamic landscape in constant, although perhaps very slow, transition, and patterns of sedimentation and erosion overprint each other repeatedly. Nevertheless, the associated rates for erosion (e.g. in the dry scenario) are likely to be very low, and not all traces of former ice ages are extinguished by later glaciations. Therefore, the spatial extent of former and more widespread glaciations can be identified by careful morphological analysis (Hauber et al. 2008; Dickson et al. 2008, 2010; Head et al. 2010).

Not all craters are necessarily expected to be exactly in the same stage of this landscape evolution. In general, however, the observations of gullies with very recent activity (e.g. Diniega et al. 2010; Dundas et al. 2010; Reiss et al. 2010) point to a late-stage situation for most mid-latitude craters at the present time. This is also in agreement with observations of current degradation of the mantling deposit in mid-latitudes (Mustard et al. 2001; Morgenstern et al. 2007; Lefort et al. 2009; Zanetti et al. 2010) and with theoretical modelling of ground-ice stability in the recent history of Mars (Chamberlain \& Boynton 2007).

The importance of snow (Figs $12 \& 13$ ) should not be neglected in assessing the relative importance of glacial and periglacial processes on Mars. Snow and nivation processes are important factors in the geomorphology of polar and cold-climate regions (e.g. Thorn 1978; Christiansen 1998), and snowpacks might be viable alternatives to glacial interpretations of some Martian surface features. Wind should also be an important factor, as it can transport snow and accumulate it in protected regions (Head et al. 2008) where it could act as a landscape-forming agent.

This study would not have been possible without the logistical support by the German-French research station AWIPEV and the kind hospitality of their staff, in particular M. Schumacher and D. Isambert. The generous help from UNIS and the Norwegian Polar Institute with transport and safety equipment for the field campaigns is highly appreciated. E. Carlsson, H. Johansson and $\mathrm{S}$. McDaniel joined the first field trip, and their companionship made it a wonderful experience. We thank the HiRISE and CTX teams for making their data publicly available. This research has been partly supported by the Helmholtz Association through the research alliance 'Planetary Evolution and Life'. Constructive comments by G. Morgan and an anonymous reviewer are greatly appreciated.

\section{References}

Åkerman, J. 1987. Periglacial forms of Svalbard: a review. In: Boardman, J. (ed.) Periglacial Processes and Landforms in Britain and Ireland. Cambridge University Press, Cambridge, 9-25. 
Anderson, D. M., Gatto, L. W. \& Ugolini, F. C. 1972. An Antarctic analog of Martian permafrost terrain Antarctic Journal of the United States, 7, 114-116.

ANDRÉ, M.-F. 1990. Frequency of debris flows and slush avalanches in Spitsbergen: a tentative evaluation from lichenometry. Polish Polar Research, 11, 345-363.

ANDRÉ, M.-F. 1994. Rock glaciers in Svalbard - tentative dating and inferred long-term velocities. Geografiska Annaler, 76A, 235-245.

ANDRÉ, M.-F. 1995. Holocene climate fluctuations and geomorphic impact of extreme events in Svalbard. Geografiska Annaler, 77A, 241-250.

Arfstrom, J. \& Hartmann, W. K. 2005. Martian flow features, moraine-like ridges, and gullies: terrestrial analogues and interrelationships. Icarus, 174, 321-335.

Arthern, R. J., Winebrenner, D. P. \& Waddington, E. D. 2000. Densification of water ice deposits on the residual North Polar Cap of Mars. Icarus, 144, 367-381.

BAKer, V. R. 2001. Water and the Martian landscape. Nature, 412, 228-236.

Ballantyne, C. K. \& Harris, C. 1994. The Periglaciation of Great Britain. Cambridge University Press, Cambridge.

Balme, M., Mangold, N. et al. 2006. Orientation and distribution of recent gullies in the southern hemisphere of Mars: observations from High Resolution Stereo Camera/Mars Express (HRSC/MEX) and Mars Orbiter Camera/Mars Global Surveyor (MOC/ MGS) data. Journal of Geophysical Research, 111, E05001, doi: 10.1029/2005JE002607.

Balme, M. R. \& Gallagher, C. 2009. An equatorial periglacial landscape on Mars. Earth and Planetary Science Letters, 285, 1-15.

Berman, D. C., Hartmann, W. K., Crown, D. A. \& BAKER, V. R. 2005. The role of arcuate ridges and gullies in the degradation of craters in the Newton Basin region of Mars. Icarus, 178, 465-486.

Berthling, I., Etzelmüller, B., Eiken, T. \& Sollid, J. L. 1998. Rock glaciers on Prins Karls Forland, Svalbard. I: internal structure, flow velocity and morphology. Permafrost and Periglacial Processes, 9, 135-145.

Bockheim, J. G., Campbell, I. B. \& McLeod, M. 2007. Permafrost distribution and active-layer depth in the McMurdo Dry Valleys, Antarctica. Permafrost and Periglacial Processes, 18, 217-227.

Byrne, S., Dundas, C. M. ET AL. 2009. Distribution of mid-latitude ground ice on Mars from new impact craters. Science, 325, 1674-1676.

Campbell, I. B. \& Claridge, G. G. C. 2004. Cryosols in the extremely arid Transantarctic Mountains region of Antarctica. In: Kimble, J. M. (ed.) Cryosols. Springer, Berlin, 415-426.

CARR, M. H. \& HeAd, J. W. 2003. Basal melting of snow on early Mars: a possible origin of some valley networks. Geophysical Research Letters, 30, 2245, doi: 10.1029/2003GL018575.

Catto, N. R. 1993. Morphology and development of an alluvial fan in a permafrost region, Aklavik Range, Canada. Geografiska Annaler, 75A, 83-93.

Chamberlain, M. A. \& Boynton, W. V. 2007. Response of Martian ground ice to orbit-induced climate change. Journal of Geophysical Research, 112, E06009, doi: 10.1029/2006JE002801.
Chevrier, V., Sears, D. W. G. ET AL. 2007. Sublimation rate of ice under simulated Mars conditions and the effect of layers of mock regolith JSC Mars-1. Geophysical Research Letters, 34, L02203, doi: 10.1029/ 2006GL028401.

Christensen, P. R. 2003. Formation of recent Martian gullies through melting of extensive water-rich snow deposits. Nature, 422, 45-48.

Christiansen, H. H. 1998. Nivation forms and processes in unconsolidated sediments, NE Greenland. Earth Surface Processes and Landforms, 23, 751-760.

Christiansen, H. H. 2005. Thermal regime of ice-wedge cracking in Adventdalen, Svalbard. Permafrost and Periglacial Processes, 16, 87-98.

Chunang, F. C. \& Crown, D. A. 2005. Surface characteristics and degradational history of debris aprons in the Tempe Terra/Mareotis fossae region of Mars. Icarus, 179, 24-42, doi: 10.1016/j.icarus.2005. 05.014 .

Clow, G. D. 1987. Generation of liquid water on Mars through the melting of a dusty snow pack. Icarus, $\mathbf{7 2}$ 95-127.

Costard, F., Forget, F., Mangold, N. \& Peulvast, J. P. 2002. Formation of recent Martian debris flows by melting of near-surface ground ice at high obliquity. Science, 295, 110-113.

Dickson, J. L. \& HeAD, J. W. 2009. The formation and evolution of youthful gullies on Mars: gullies as the late-stage phase of Mars' most recent ice age. Icarus, 204, 63-86.

Dickson, J. L., Head, J. W. \& Kreslavsky, M. 2007. Martian gullies in the southern mid-latitudes of Mars: evidence for climate-controlled formation of young fluvial features based upon local and global topography. Icarus, 188, 315-323.

Dickson, J. L., Head, J. W. \& Marchant, D. R. 2008. Late Amazonian glaciation at the dichotomy boundary on Mars: evidence for glacial thickness maxima and multiple glacial phases. Geology, 36, 411-414.

Dickson, J. L., Head, J. W. \& Marchant, D. R. 2010. Kilometer-thick ice accumulation and glaciation in the northern mid-latitudes of Mars: evidence for craterfilling events in the Late Amazonian at the Phlegra Montes. Earth and Planetary Science Letters, 294, 332-342.

DiJKmans, J. W. A. 1990. Niveo-aeolian sedimentation and resulting sedimentary structures; Søndre Strømfjord area, Western Greenland. Permafrost and Periglacial Processes, 1, 83-96.

Diniega, S., Byrne, S., Bridges, N. T., Dundas, C. M. \& McEwen, A. S. 2010. Present-day Martian dune gully activity. In: Proceedings of the 41st Annual Lunar and Planetary Science Conference, March 1-5, 2010, The Woodlands, Texas. Lunar and Planetary Institute, Houston, TX, Abstract 2216.

Doran, P. T., McKay, C. P., Clow, G. D., Dana, G. L., Fountain, A. G., Nylen, T. \& Lyons, W. B. 2002. Valley floor climate observations from the McMurdo Dry Valleys, Antarctica, 1986-2000. Journal of Geophysical Research, 107, 4772, doi: 10.1029/ 2001JD002045.

Dundas, C. M. \& McEwen, A. S. 2010. An assessment of evidence for pingos on Mars using HiRISE. Icarus, 205 244-258. 
Dundas, C. M., McEwen, A. S., Diniega, S., Byrne, S. \& Martinez-Alonso, S. 2010. New and recent gully activity on Mars as seen by HiRISE. Geophysical Research Letters, 37, L07202, doi: 10.1029/ 2009GL041351.

Dundas, C. M., Mellon, M. T., McEwen, A. S., Lefort, A., Keszthelyi, L. P. \& Thomas, N. 2008. HiRise observations of fractured mounds: possible Martian pingos. Geophysical Research Letters, 35, L04201, doi: 10.1029/2007GL031798.

Etzelmüller, B. \& Hagen, J. O. 2005. Glacierpermafrost interaction in Arctic and alpine mountain environments with examples from southern Norway and Svalbard. In: Harris, C. \& Murton, J. B. (eds) Cryospheric Systems: Glaciers and Permafrost. Geological Society, London, Special Publications, 242, $11-27$.

Fanale, F. P., Salvail, J. R., Zent, A. P. \& Postawko, S. E. 1986. Global distribution and migration of subsurface ice on Mars. Icarus, 67, 1-18.

Fassett, C. I. \& Head, J. W. 2006. Valleys on Hecates Tholus, Mars: origin by basal melting of summit snowpack. Planetary and Space Science, 54, 370-378.

Fassett, C. I., Dickson, J. L., Head, J. W., LeVy, J. S. \& Marchant, D. R. 2010. Supraglacial and proglacial valleys on Amazonian Mars. Icarus, 208, 86-100.

Forget, F., Haberle, R. M., Montmessin, F., Levrard, B. \& HEAD, J. W. 2006. Formation of Glaciers on Mars by Atmospheric Precipitation at High Obliquity. Science, 311, 368-371.

Gooding, J. L. 1986. Martian dust particles as condensation nuclei - A preliminary assessment of mineralogical factors. Icarus, 66, 56-74.

Gwinner, K., Coltelli, M. et al. 2006. The HRSC-AX Mt Etna Project: High-Resolution Orthoimages and $1 \mathrm{~m}$ DEM at Regional Scale. International Archives of Photogrammetry and Remote Sensing, XXXVI (Part 1), http://isprs.free.fr/documents/Papers/T0523.pdf.

Gwinner, K., Scholten, F. et al. \& The HRSC Co-Investigator Team 2005. Hochauflösende Digitale Geländemodelle auf der Grundlage von Mars Express HRSC-Daten. Photogrammetrie, Fernerkundung, Geoinformation, 5/2005, 387-394.

Gwinner, K., Scholten, F. et al. 2009. Derivation and validation of high-resolution digital elevation models from Mars Express HRSC-data. Photogrammetric Engineering \& Remote Sensing, 75, 1127-1142.

Gwinner, K., Scholten, F. ET AL. 2010. Topography of Mars from global mapping by HRSC high-resolution digital elevation models and orthoimages: characteristics and performance. Earth and Planetary Science Letters, 294, 506-519.

HaeberLI, W. 1979. Holocene push-moraines in Alpine permafrost. Geografiska Annaler, 61A, 43-48.

HaEberLI, W. 1985. On the morphodynamics of ice/ debris-transport systems in cold mountain areas. Norsk Geografisk Tidsskrift, 50, 3-9.

HAEBerli, W. 2005. Investigating glacier-permafrost relationships in high-mountain areas: historical background, selected examples and research needs. In: Harris, C. \& Murton, J. B. (eds) Cryospheric Systems: Glaciers and Permafrost. Geological Society, London, Special Publications, 242, 29-37.
Hanssen-Bauer, I. \& Førland, E. J. 1998. Long-term trends in precipitation and temperature in the Norwegian Arctic: can they be explained by changes in atmospheric circulation patterns? Climate Research, 10, $143-153$.

Hauber, E., Preusker, F. et al. 2009. Morphometry of alluvial fans in a polar desert (Svalbard, Norway): implications for Interpreting Martian Fans. In: Proceedings of the 41st Annual Lunar and Planetary Science Conference, March 1-5, 2010, The Woodlands, Texas. Lunar and Planetary Institute, Houston, TX, Abstract 1468.

Hauber, E., van Gasselt, S., Chapman, M. G. \& Neukum, G. 2008. Geomorphic evidence for former lobate debris aprons at low latitudes on Mars: indicators of the Martian paleoclimate. Journal of Geophysical Research, 113, E02007, doi: 10.1029/ 2007JE002897.

Head, J. W. \& Marchant, D. R. 2003. Cold-based mountain glaciers on Mars: Western Arsia Mons. Geology, 31, 641-644.

Head, J. W., Marchant, D. R., Agnew, M. C., Fassett, C. I. \& Kreslavsky, M. A. 2006. Extensive valley glacier deposits in the northern mid-latitudes of Mars: evidence for Late Amazonian obliquity-driven climate change. Earth and Planetary Science Letters, 241, 663-671.

Head, J. W., Marchant, D. R., Dickson, J. L., Kress, A. M. \& BAKER, D. M. 2010. Northern mid-latitude glaciation in the Amazonian period of Mars: criteria for the recognition of debris-covered glacier and valley glacier landsystem deposits. Earth and Planetary Science Letters, 294, 306-320.

Head, J. W., Marchant, D. R. \& Kreslavsky, M. A. 2008. Formation of gullies on Mars: link to recent climate history and insolation microenvironments implicate surface water flow origin. Proceedings of the National Academy of Sciences, 105, 13,258-13,263.

Head, J. W., Mustard, J. F., Kreslavsky, M. A., MilliKEN, R. E. \& Marchant, D. R. 2003. Recent ice ages on Mars. Nature, 426, 797-802.

Hecht, M. H. 2002. Metastability of liquid water on Mars. Icarus, 156, 373-386.

Holt, J. W., SAFAeinili, A. ET AL. 2008. Radar sounding evidence for buried glaciers in the southern midlatitudes of Mars. Science, 322, 1235-1238.

Hsu, K. J. 1975. Catastrophic debris streams (sturzstroms) generated by rockfalls. Geological Society of America Bulletin, 86, 129-140.

Humlum, O. 2005. Holocene permafrost aggradation in Svalbard. In: HARris, C. \& MurTon, J. B. (eds) Cryospheric Systems: Glaciers and Permafrost. Geological Society, London, Special Publications, 242, 11-27.

Humlum, O. \& Christiansen, H. H. 2008. Lowland periglacial research: a review of published advances 2003-2007. Permafrost and Periglacial Processes, 19, 211-235.

IsAKSEN, K., ØDEgÅRD, R. S., EIKEN, T. \& Sollid, J. L. 2000. Composition, flow and development of two tongue-shaped rock glaciers in the permafrost of Svalbard. Permafrost and Periglacial Processes, 11, 241-257.

IVERSON, R. M. 1997. The physics of debris flows. Reviews of Geophysics, 35, 245-296. 
Iverson, R. M., Reid, M. E. \& LAHusen, R. G. 1997. Debris-flow mobilization from landslides. Annual Review of Earth and Planetary Sciences, 25, 85-138.

JAKOSKY, B. M. \& CARR, M. H. 1985. Possible precipitation of ice at low latitudes of Mars during periods of high obliquity. Nature, 315, 559-561.

Jakosky, B. M., Henderson, B. G. \& Mellon, M. T. 1995. Chaotic obliquity and the nature of the Martian climate. Journal of Geophysical Research, 100, $1579-1584$.

Johnson, P. G. 1995. Debris transfer and sedimentary environments: Alpine glaciated areas. In: SLAYMAKER, O. (ed.) Steepland Geomorphology. Wiley, Chichester, 27-44.

Kadish, S. J., Barlow, N. G. \& Head, J. W. 2009. Latitude dependence of Martian pedestal craters: evidence for a sublimation-driven formation mechanism. Journal of Geophysical Research, 114, E10001, doi: 10.1029/2008JE003318.

Kahn, R. A., Martin, T. Z., Zurek, R. W. \& Lee, S. W. 1992. The Martian dust cycle. In: Kieffer, H. H., JAKowsky, B. M., Snyder, C. \& Matthews, M. (eds) Mars. University of Arizona Press, Tucson, AZ, 1017-1053.

Kneissl, T., Reiss, D., van Gasselt, S. \& Neukum, G. 2010. Distribution and orientation of northernhemisphere gullies on Mars from the evaluation of HRSC and MOC-NA data. Earth and Planetary Science Letters, 294, 357-367.

Kossacki, K. J. \& Markiewicz, W. J. 2004. Seasonal melting of surface water ice condensing in Martian gullies. Icarus, 171, 272-283.

Koster, E. A. 1988. Ancient and modern cold-climate aeolian sand deposition: a review. Journal of Quaternary Science, 3, 69-83.

Koster, E. A. \& Dijkmans, J. W. A. 1988. Niveo-aeolian deposits and denivation forms, with special reference to the Great Kobuk Sand Dunes, Northwestern Alaska. Earth Surface Processes and Landforms, 13, 153-170.

Kreslavsky, M. A. \& Head, J. W. 2000. Kilometerscale roughness of Mars: results from MOLA data analysis. Journal of Geophysical Research, 105, 26695-26712.

Kreslavsky, M. A. \& Head, J. W. 2002. Mars: nature and evolution of young latitude-dependent water-ice-rich mantle. Geophysical Research Letters, 29, 1719, doi: 10.1029/2002GL015392.

Kreslaysky, M. A., Head, J. W. \& Marchant, D. R. 2008. Periods of active permafrost layer formation during the geological history of Mars: implications for circum-polar and mid-latitude surface processes. Planetary and Space Science, 56, 289-302.

Lanza, N. L., Meyer, G. A., Okubo, C. H., Newsom, H. E. \& WiENS, R. C. 2010. Evidence for debris flow gully formation initiated by shallow subsurface water on Mars. Icarus, 205, 103-112.

LARSSON, S. 1982. Geomorphological effects on the slopes of Longyear Valley, Spitsbergen, after a heavy rainstorm in July 1972. Geografiska Annaler, 64A, $105-125$.

Laskar, J., Correia, A. C. M., Gastineau, M., Joutel, F., Levrard, B. \& Robutel, P. 2004. Long term evolution and chaotic diffusion of the insolation quantities of Mars. Icarus, 170, 343-364.

Lefort, A., Russell, P. S., Thomas, N., McEwen, A. S., DunDAS, C. M. \& KIRK, R. L. 2009. Observations of periglacial landforms in Utopia Planitia with the High Resolution Imaging Science Experiment (HiRISE). Journal of Geophysical Research, 114, E04005, doi: 10.1029/2008JE003264.

Leighton, R. R. \& Murray, B. C. 1966. Behavior of carbon dioxide and other volatiles on Mars. Science, 153, 136-144.

Levrard, B., Forget, F., Montmessin, F. \& Laskar, J. 2004. Recent ice-rich deposits formed at high latitudes on Mars by sublimation of unstable equatorial ice during low obliquity. Nature, 431, 1072-1075.

Levy, J. S., Head, J. W. \& Marchant, D. R. 2009a. Cold and dry processes in the Martian Arctic: Geomorphic observations at the Phoenix landing site and comparisons with terrestrial cold desert landforms. Geophysical Research Letters, 36, L21203, doi: 10.1029/ 2009GL040634.

Levy, J. S., Head, J. W. \& Marchant, D. R. $2009 \mathrm{~b}$. Thermal contraction crack polygons on Mars: classification, distribution, and climate implications from HiRISE observations. Journal of Geophysical Research, 114, E01007, doi: 10.1029/ 2008JE003273.

Levy, J. S., Head, J. W., Marchant, D. R., Dickson, J. L. \& Morgan, G. A. 2009c. Geologically recent gullypolygon relationships on Mars: insights from the Antarctic Dry Valleys on the roles of permafrost, microclimates, and water sources for surface flow. Icarus, 201, 113-126.

Levy, J. S., Head, J. W., Dickson, J. L., Fassett, C. I., Morgan, G. A. \& Schon, S. C. 2010. Identification of gully debris flow deposits in Protonilus Mensae, Mars: characterization of a water-related, energetic gully-forming process. Earth and Planetary Science Letters, 294, 368-377.

LIESTøL, O. 1976. Pingos, springs and permafrost in Spitsbergen. Norsk Polarinstitutt Arrbok, 1975, 7-29.

LøNNE, I. \& Nemec, W. 2004. High-arctic fan delta recording deglaciation and environment disequilibrium. Sedimentology, 51, 553-589.

Lukas, S., Nicholson, L. I., Ross, F. H. \& Humlum, O. 2005. Formation, meltout processes and landscape alteration of high-arctic ice-cored moraines examples from Nordenskiöld land, Central Spitsbergen. Polar Geography, 29, 157-187.

Mackay, J. R. 1998. Pingo growth and collapse, Tuktoyaktuk Peninsula area, Western Arctic Coast, Canada: a long term field study. Geographique physique et Quaternaire, 52, 271-323.

Madeleine, J.-B., Forget, F., Head, J. W., Levrard, B., Montmessin, F. \& Millour, E. 2009. Amazonian northern mid-latitude glaciation on Mars: a proposed climate scenario. Icarus, 203, 390-405, doi: 10.1016/j.icarus.2009.04.037

Mangerud, J., Bolstad, M. ET AL. 1992. The last glacial maximum on Spitsbergen, Svalbard. Quaternary Research, 38, 1-39.

MangOLD, N. 2005. High latitude patterned grounds on Mars: classification, distribution and climatic control. Icarus, 174, 336-359. 
Marchant, D. R. \& Head, J. W. 2007. Antarctic Dry Valleys: microclimate zonation, variable geomorphic processes, and implications for assessing climate change on Mars. Icarus, 192, 187-222.

Marchant, D. R. \& Head, J. W. 2010. Geologic analogies between the surface of Mars and the McMurdo Dry Valleys: microclimate-related geomorphic features and evidence for climate change. In: Doran, P. T., Lyons, W. B. \& McKnight, D. M. (eds) Life in Antarctic Deserts and Other Cold Dry Environments. Cambridge University Press, Cambridge, 9-77.

Marchant, D. R., Lewis, A., Phillips, W. C., Moore, E. J., Souchez, R. \& Landis, G. P. 2002. Formation of patterned-ground and sublimation till over Miocene glacier ice in Beacon Valley, Antarctica. Geological Society of America Bulletin, 114, 718-730.

Mellon, M. T. \& JAKosky, B. M. 1993. Geographic variations in the thermal and diffusive stability of ground ice on Mars. Journal of Geophysical Research, 98, 3345-3364.

Mellon, M. T. \& JAKosky, B. M. 1995. The distribution and behavior of Martian ground ice during past and present epochs. Journal of Geophysical Research, 100, $11781-11799$.

Mellon, M. T., Arvidson, R. E. ET AL. 2009. Ground ice at the Phoenix Landing Site: stability state and origin. Journal of Geophysical Research, 114, E00E07, doi: 10.1029/2009JE003417.

Milliken, R. E., Mustard, J. F. \& Goldsby, D. L. 2003. Viscous flow features on the surface of Mars: observations from high-resolution Mars Orbiter Camera (MOC) images. Journal of Geophysical Research, 108, 5057, doi: 10.1029/2002JE002005.

Mischna, M. A., Richardson, M. I., Wilson, R. J. \& McCleESE, D. J. 2003. On the orbital forcing of Martian water and $\mathrm{CO}_{2}$ cycles: a general circulation model study with simplified volatile schemes. Journal of Geophysical Research, 108, 5062, doi: 10.1029/2003JE002051.

Möhlmann, D. T. F. 2010. Temporary liquid water in upper snow/ice sub-surfaces on Mars? Icarus, 207, $140-148$.

Morgan, G. A., Head, J. W., Forget, F., Madeleine, J.-B. \& SpIGA, A. 2010. Gully formation on Mars: two recent phases of formation suggested by links between morphology, slope orientation and insolation history. Icarus, 208, 658-666.

Morgenstern, A., Hauber, E., Reiss, D., van Gasselt, S., Grosse, G. \& Schirrmeister, L. 2007. Deposition and degradation of a volatile-rich layer in Utopia Planitia and implications for climate history on Mars. Journal of Geophysical Research, 112, E06010, doi: 10.1029/2006JE002869.

Mustard, J. F., Cooper, C. D. \& Rifkin, M. K. 2001. Evidence for recent climate change on Mars from the identification of youthful near-surface ground ice. Nature, 412, 411-414.

Müller, F. 1959. Beobachtungen über Pingos. Meddelelser om Gronland, 153, 1-127.

ØDEgÅrd, R. S., Isaksen, K., EIKen, T. \& Sollid, J.-L. 2003. Terrain analyses and surface velocity measurements of the Hiorthfjellet rock glacier, Svalbard. Permafrost and Periglacial Processes, 14, 359-365.
Paterson, W. S. B. 1994. The Physics of Glaciers, 3rd edn. Pergamon, Oxford.

Perron, J. T., Dietrich, W. E., Howard, A. D., McKean, J. A. \& Pettinga, J. R. 2003. Ice-driven creep on Martian debris slopes. Geophysical Research Letters, 30, 1747, doi: 10.1029/2003GL017603.

PierCe, T. L. \& Crown, D. A. 2003. Morphologic and topographic analyses of debris aprons in the eastern Hellas region, Mars. Icarus, 163, 46-65.

Reid, M. E., Nielsen, H. P. \& Dreiss, S. J. 1988. Hydrologic factors triggering a shallow hillslope failure. Bulletin of the Association of Engineering Geologists, 25, 349-361.

Reiss, D., van Gasselt, S., Neukum, G. \& Jaumann, R. 2004. Absolute dune ages and implications for the time of formation of gullies in Nirgal Vallis, Mars. Journal of Geophysical Research, 109, E06007, doi: 10.1029/ 2004JE002251.

Reiss, D., Hiesinger, H., Hauber, E. \& Gwinner, K. 2009. Regional differences in gully occurrence on Mars: a comparison between the Hale and Bond craters. Planetary and Space Science, 57, 958-974.

Reiss, D., Erkeling, G., Bauch, K. E. \& Hiesinger, H. 2010. Evidence for present day gully activity on the Russell crater dune field, Mars. Geophysical Research Letters, 37, L06203, doi: 10.1029/ 2009 GL042192.

Scholten, F. \& Gwinner, K. 2004. Operational parallel processing in digital photogrammetry - strategy and results using different multi-line cameras. International Archives of Photogrammetry and Remote Sensing, XXXIV, 408-413.

Scholten, F., Gwinner, K. et al. \& The HRSC Co-Investigator Team 2005. Mars Express HRSC data processing - methods and operational aspects. Photogrammetric Engineering \& Remote Sensing, 71, 1143-1152.

Schon, S. C., Head, J. W. \& Fassett, C. I. 2009a. Unique chronostratigraphic marker in depositional fan stratigraphy on Mars: evidence for $\sim 1.25 \mathrm{Ma}$ old gully activity and surficial meltwater origin. Geology, 37, 207-210.

Schon, S. C., Head, J. W. \& Milliken, R. E. 2009b. A recent ice age on Mars: evidence for climate oscillations and the buried ice hypothesis revealed by regional layering in dissected mid-latitude mantling deposits. Geophysical Research Letters, 36, L15202, doi: 10.1029/2009GL038554.

Schorghofer, N. 2007. Dynamics of ice ages on Mars. Nature, 449, 192-194.

Schorghofer, N. \& Edgett, K. S. 2006. Seasonal surface frost at low latitudes on Mars. Icarus, 180, $321-334$.

ShaKesby, R. A. 1997. Pronival (protalus) ramparts: a review of forms, processes, diagnostic criteria and palaeoenvironmental implications. Progress in Physical Geography, 21, 394-418.

Shakesby, R. A., Dawson, A. G. \& Matthews, J. A. 1987. Rock glaciers, protalus ramparts and related phenomena, Rondane, Norway: a continuum of large-scale talus-derived landforms. Boreas, 16, $305-317$.

ShumskiI, P. A. 1964. Principles of Structural Glaciology. Dover, New York. 
Shuster, D. L. \& Weiss, B. P. 2005. Martian surface paleotemperatures from thermochronology of meteorites. Science, 309, 597.

Smith, P. H., TAmppari, L. K. ET AL. 2009. $\mathrm{H}_{2} \mathrm{O}$ at the Phoenix landing site. Science, 325, 58-61.

SMoluchowski, R. 1968. Mars: retention of Ice. Science, 159, $1348-1350$.

Soare, R. J., Burr, D. M. \& Wan Bun Tseung, J.-M. 2005. Possible pingos and a periglacial landscape in northwest Utopia Planitia. Icarus, 174, 373-382.

Soderblom, L. A., Kreidler, T. J. \& Masursky, H. 1973. Latitudinal distribution of a debris mantle on the Martian surface. Journal of Geophysical Research, 78, 4117-4122.

Sørbel, L. \& TOLGENSBAKK, J. 2002. Ice-wedge polygons and solifluction in the Adventdalen area, Spitsbergen, Svalbard. Norsk Geografisk Tidsskrift, 56, 62-66.

Sollid, J. L., Holmlund, P., Isaksen, K. \& Harris, C. 2000. Deep permafrost boreholes in western Svalbard, northern Sweden and southern Norway. Norsk Geografisk Tidsskrift, 54, 186-191.

SquYres, S. W. 1978. Martian fretted terrain - Flow of erosional debris. Icarus, 34, 600-613.

Thorn, C. E. 1978. The geomorphic role of snow. Annals of the Association of American Geographers, 68, 414-425.

Thorn, C. E. 1988. Nivation: a geomorphic chimera. In: Clark, M. J. (ed.) Advances in Periglacial Geomorphology. Wiley, Chichester, 3-31.

Tolgensbakk, J., Sørbel, L. \& Høgvard, K. 2000. Adventdalen, Geomorphological and Quaternary Geological Map of Svalbard, scale 1:100,000. Spitsbergen Sheet $C 9 Q$. Norsk Polarinstitutt Temakart, Troms $\varnothing, 32$.

Toon, O. B., Pollack, J. B., Ward, W., Burns, J. A. \& BILSKI, K. 1980. The astronomical theory of climatic change on Mars. Icarus, 44, 552-607.

Touma, J. \& Wisdom, J. 1993. The chaotic obliquity of Mars. Science, 259, 1294-1297.

VAN EVERDINGEN, R. (ed.). 2005. Multi-language Glossary of Permafrost and Related Ground-ice Terms. National Snow and Ice Data Center/World Data Center for Glaciology, Boulder, CO. World Wide Web Address: http://nsidc.org/fgdc/glossary.

Van Gasselt, S., Reiss, D., Thorpe, A. K. \& Neukum, G. 2005. Seasonal variations of polygonal thermal contraction crack patterns in a south polar trough, Mars. Journal of Geophysical Research, 110, E08002, doi: 10.1029/2004JE002385.

Van Gasselt, S., Hauber, E. \& Neukum, G. 2010. Lineated valley fill at the Martian dichotomy boundary: nature and history of degradation. Journal of
Geophysical Research, 115, E08003, doi: 10.1029/ 2009JE003336.

Vincendon, M., Mustard, J., Forget, F., Kreslavsky, M., Spiga, A., Murchie, S. \& Bibring, J.-P. 2009. Mid latitude $\mathrm{CO}_{2}$ ice deposits analyzed with CRISM and OMEGA. In: Third International Workshop on Mars Polar Energy Balance and the $\mathrm{CO}_{2}$ Cycle, held July 21-24, 2009 in Seattle, Washington. Lunar and Planetary Institute, Houston, TX. LPI Contribution No. 1494, abstract 7021, pp. 61-62.

Vincendon, M., Forget, F. \& Mustard, J. $2010 a$. Water ice at low to mid latitudes on Mars. Journal of Geophysical Research, 115, E10001, doi: 10.1029/ $2010 J E 003584$.

Vincendon, M., Mustard, J., Forget, F., Kreslavsky, M., Spiga, A., Murchie, S. \& Bibring, J.-P. $2010 b$. Near-tropical subsurface ice on Mars. Geophysical Research Letters, 37, L01202, doi: 10.1029/ 2009 GL041426.

WALKer, A. S. 1997. Deserts - Geology and Resources. USGS Online Book. World Wide Web Address: http://pubs.usgs.gov/gip/deserts/.

WARD, W. R. 1973. Large-scale variations in the obliquity of Mars. Science, 181, 260-262.

Wewel, F., Scholten, F. \& Gwinner, K. 2000. High Resolution Stereo Camera (HRSC) - Multispectral 3D-data acquisition and photogrammetric data processing. Canadian Journal of Remote Sensing, 26, 466-474.

Williams, K. E., Toon, O. B., Heldmann, J. L., McKay, C. \& Mellon, M. T. 2008. Stability of mid-latitude snowpacks on Mars. Icarus, 196, 565-577.

Williams, K. E., Toon, O. B., Heldmann, J. L. \& Mellon, M. T. 2009. Ancient melting of mid-latitude snowpacks on Mars as a water source for gullies. Icarus, 200, 418-425.

Worsley, P. \& GuRney, S. D. 1996. Geomorphology and hydrogeological significance of the Holocene pingos in the Karup Valley area, Traill Island, northern east Greenland. Journal of Quaternary Science, 11, 249-262.

YoshiKawa, K. 1993. Notes on open-system pingo ice, Adventdalen, Spitsbergen. Permafrost and Periglacial Processes, 4, 327-334.

Yoshikawa, K. \& Harada, K. 1995. Observations on nearshore pingo growth, Adventdalen, Spitsbergen. Permafrost and Periglacial Processes, 6, 361-372.

Zanetti, M., Hiesinger, H., Reiss, D., Hauber, E. \& Neukum, G. 2010. Distribution and evolution of scalloped terrain in the southern hemisphere, Mars. Icarus, 206, 691-706. 